\title{
Caddelerdeki Değişimin Mekânsal Etkileri Üzerine Bir Araştırma: Samsun Çiftlik Caddesi ${ }^{1}$
}

\author{
Erkan Avlar ${ }^{2}$ \\ ORCID: 0000-0003-0492-8095
}

\author{
Burcu Yazici ${ }^{3}$ \\ ORCID: 0000-0002-9932-2979
}

Öz

Kamusal alan olan caddelerdeki değişim, birçok farklı uygulamanın yanı sıra, caddelerin yayalaştırlmasın ve caddeye arayüz oluşturan binaları yenilenmesini de kapsar. Kent yollarnnı yalnizca yürünebilen alanlar olarak düzenlenmesi ve yürüyenlere daha geniş alanlar ayrlmast için, caddelerde yayalaştırma yapılmaktadır. Zaman içinde bina cepheleri birçok etkene bağl olarak, kullanic gereksinimlerine ve isteklerine yant veremez duruma geldiğinde ise cepheler yenilenmektedir. Samsun Çiftlik Caddesi de yayalaştırlan ve bina cepheleri yenilenen kentsel mekânlardan biridir.

Çalşmanın amacl; projenin kente estetik, sosyal ve ekonomik yönden ne düzeyde değer katttğının, caddenin yayalaştırlması ve bina cephelerinin yenilenmesiyle nasil bir sonuç elde edildiğinin, caddedeki değişimden dolayı kullanıcı memnuniyetinin hangi düzeyde olduğunun ve caddedeki değ̈işimin sorunlara yol açıp açmadı̆̆ının sorgulanmasıdır. Bu amaçla Samsun Çiftlik Caddesi'nin fiziki durumu incelenmiş, mekânsal özellikleri belirlenmiş ve caddede yapılan değişiklikten kullanıcılarn memnuniyet düzeyi ölçülmüştür. Çalışma sonucunda elde edilen verilere göre, Çiftlik Caddesi'nin mekânsal kalitesinin ve kullanıcı memnuniyetinin arttırlması için öneriler geliştirilmektedir.

Anahtar Kelimeler: Caddelerde değişim, caddelerde yayalaştırma, binalarda cephe yenileme, Samsun Çiftlik Caddesi

\footnotetext{
${ }^{1}$ Bu çalışma, Burcu Yazıcı'nın “Kentsel Mekânlarda Yayalaştırma ve Cephelerin Yenilenmesi: Samsun Çiftlik Caddesi Örneği" başlıklı yüksek lisans tezinin geliştirilmesi sonucu üretilmiştir.

${ }^{2}$ Doç. Dr., Yıldız Teknik Üniversitesi, E-mail: eavlar@yildiz.edu.tr

${ }_{3}^{3}$ Yıldız Teknik Üniversitesi, E-mail: burcuyazici90@gmail.com

idealkent @ Kent Araştırmaları Dergisi (Journal of Urban Studies) 


\title{
A Research on the Spatial Effects of Changes in Streets: Samsun Çiftlik Street
}

\author{
Erkan Avlar 4 \\ ORCID: 0000-0003-0492-8095
}

\author{
Burcu Yazıc1 ${ }^{5}$ \\ ORCID: 0000-0002-9932-2979
}

\begin{abstract}
Changes in streets - which are public spaces - include many different applications ranging from the pedestrianization of streets to the renewal of buildings that front streets. Pedestrianization is carried out in order to designate city roads as strictly walkable areas and to allocate wider areas to pedestrians. Building façades are renovated when, over time, they cease to respond to user requirements and demands due to various factors. Samsun Çiftlik Street is an example of an urban space that has been pedestrianized and whose building façades have been renovated.

The purpose of this study is to investigate the level of value added to the city in aesthetic, social and economic terms, the consequences of pedestrianizing the street and renovating the building façades, the level of user satisfaction regarding the changes to the street, and whether these changes lead to problems. For this purpose, the physical condition of Samsun Çiftlik Street was examined, its spatial properties were determined, and users' satisfaction levels of the changes to the street were measured. Recommendations are being developed to improve the spatial quality of Çiftlik Street and to increase user satisfaction in line with the study's resulting data.
\end{abstract}

Keywords: Change in the streets, pedestrianization in the streets, renovating building facades, Samsun Çiftlik Street

\footnotetext{
${ }^{4}$ Assoc. Prof. Dr., Yıldız Technical University, E-mail: eavlar@yildiz.edu.tr

${ }^{5}$ Yıldız Technical University, E-mail: burcuyazici90@gmail.com

idealkent (c) Kent Araştırmaları Dergisi (Journal of Urban Studies) 


\section{Giriş}

Caddeler, kentin kamusal alanları ve doğrusal yapıda olan kent parçalarıdır. Genel olarak bir caddenin; ulaşımı sağlayan bir hareket kanalı, kamusal yaşamı barındıran kentsel bir mekân ve mimari yapıların sınırı olması şeklinde üç fiziksel rolü bulunmaktadır (Marshall, 2005). Caddeleri mekân haline getiren ve yaşanır kılan bileşenler ise; caddeye sınır oluşturan yapılar ve onunla kesişen yollar, kent donatıları ve kullanıcılardır. Sosyal yaşamın önemli yerlerinden biri olan caddeler, kolay ve hızlı bir biçimde erişilebilecek dış mekânlar olarak görülmektedir. İyi bir caddede amaçlanan, kent halkının gereksinimlerinin karşılanması ve bir yerden bir yere hareketlerinin kolaylaştırılmasıdır (Jacobs, 1993).

Kentin en dinamik mekânları olan caddeler sürekli değişim içindedir. Caddelerdeki değişimler, kentsel yaşama ve caddeye farklı olanaklar sunarken, bazen de sorunlara neden olabilmektedir (Pekşen, 2015, s.25). Son yıllarda, birçok kentteki caddelerde değişim yaşanmakta ve yerel yönetimler değişim projelerine öncelik vermektedir. Bu değişimler; yol kullanım biçiminin değişmesi, altyapı sistemlerinin yenilenmesi, kaldırımların genişletilmesi veya daraltılması, yol kaplamalarının yenilenmesinin yanı sıra, caddeye cephesi olan binaların yenilenmesini de kapsar.

Caddelerdeki önemli değişimlerden biri yayalaştırma çalışmasıdır. Yayalaştırma, kent yollarının bir bölümünün yalnızca yürünebilen alanlar haline getirilmesi veya yürüyenlere daha geniş alanlar ayrılmasıdır (Keleş, 1980). Yayalaştırma çalışmalarının temel nedenleri; kentsel ekonomi, kentsel kalite ve sosyal refah şeklinde sıralanmaktadır (Brambilla ve Longo, 1977). $\mathrm{Bu}$ tür uygulamalarda, bir ticaret aksı oluşturularak perakende ticaretin arttırılması ve kentsel ekonominin canlandırılması hedeflenmektedir. Böylece yayalaştırılan alanlarda, yaya ayak izinin artmasıyla birlikte ekonomik yönden hareketlilik de beklenmektedir. Ayrıca yayalaştırmanın nedenleri arasında; insanların birbirleriyle olan ilişkilerinin geliştirilmesi, dinlenme mekânlarının tasarlanması, sosyal hayatın canlandırılması, tarihi binaların ve kent dokusunun korunması, kent merkezinin daha düzenli ve kullanılabilir hale getirilmesi, konut alanlarının iyileştirilmesi ve çevrenin estetik değerinin artırılması da bulunmaktadır (Altunbaş, 2006, s.14-15).

Caddelerdeki önemli değişimlerden bir diğeri de bina cephelerinin yenilenmesidir. Cephe, dışarıdan bakıldığında bir binada ilk olarak algılanan, dış ve iç ortam arasında ayırıcı ve dış ortama karşı koruyucu görevi olan, atmosferle doğrudan temas halinde bulunan diş kabuktur (Karaman- 
lıoğlu, 2011, s.4). Zaman içinde dış kabuk, dış ortam koşullarının etkisiyle özelliklerini kaybetmekte, değişen teknoloji, kullanıc profili ve yasal düzenlemeler nedeniyle kullanicı gereksinimlerine ve isteklerini yanit veremez duruma gelmektedir. Binaların performansı üzerinde önemli etkiye sahip olan cepheler, dış çevre koşullarıyla doğrudan ilişki içinde olduklarından, diğer yapı elemanlarına oranla daha hızlı eskimektedir. Bunun için, cephelerde yenileme gereksinimi oluşması kaçınılmazdır (Başarır ve Şahin Diri, 2014, s. 109).

Cephe yenileme, dış etkenlerden kaynaklanan sorunların giderilmesi, binanın mimari kimliğinin korunması ve enerjinin daha verimli kullanılması gibi yararlar sağlamaktadır. Kapsamlı şekilde yenilenmiş bir cephe, binanın enerji verimliliğini \%50 veya daha fazla oranda arttırabilmekte ve yenilenebilir enerji kullanımının düzeyini belirleyebilmektedir. Binada her türlü konfor artışı, ekonomik koşullarla bağlantılı olarak yarar sağlamaktadır (Jacob, 2007, s.1). Ancak yapı sahiplerini ikna etmek için isteklendirmek gereklidir. Cephelerde yenileme kararlarının belirleyici nedenleri; performans sorunları, karar vericilerin yenileme istekleri ve yasaların getirdiğ $i$ zorunluluklar olarak sıralanabilir. Bir cephede yenileme kararı verebilmek için, öncelikle performans sorunlarına neden olan eksiklerin ve hasarların iyi belirlenmesi gereklidir. Karar vericilerin yenileme isteği, cephenin kişisel beklentileri karşılayamaması sonucu ortaya çıkmaktadır. Yasaların getirdiği zorunluluklar ise, yenilemenin kişisel irade dışında gerçekleştirilmesinde zorunlu bir durum oluşturmaktadır (Erturan ve Eren, 2018, s.26).

Samsun Çiftlik Caddesi, yayalaştırılan ve bina cepheleri yenilenen kentsel mekânlardan biridir. Bu caddedeki yayalaştırma ve cephe yenileme çalışmaları, Samsun Kent Estetik Kurulu tarafından alınan kararlar doğrultusunda ve Karadeniz Binaları Enerji Verimliliği Planı (BSBEEP) projesi kapsaminda gerçekleştirilmiştir. Kent Estetik Kurulu, Samsun Büyükşehir Belediyesi'nin 2015-2019 stratejik planında, yerleşik ve yerleşime yeni açlacak alanlarda; şehrin estetiğine, tarihine ve doğal değerlerine uygun ilke kararları geliştirmek, kentsel tasarım projelerini değerlendirmek ve görüntü kirliliğine yol açan yapılar ile bu yapıların çevresinde farklı amaçlarla yapılan uygulamaları engellemek üzere oluşturulmuştur (Samsun Büyükşehir Belediyesi, 2014, s.42). Çiftlik Caddesi Alışveriş Merkezi olarak adlandırılan değişim projesi, \%75'i bina sahipleri, \%25'i Samsun Büyükşehir Belediyesi tarafından maddi olarak desteklenen bir projedir (Sezgin, 2015, s.19). Hem caddeye hem de caddeye arayüz oluşturan binalara yeni bir kimlik kazandırmak için hazırlanan ve Çiftlik Caddesi'nin güçlü bir alışveriş aksı olması 
beklenen bu kentsel proje çalışmasında, caddenin taşıt trafiğinden arındırılması, alt yapının ve bina dış cephelerinin yenilenmesi hedeflenmiştir.

\section{Çalışma Alanı ve Yöntem}

Çalışma alanı, Türkiye'nin Orta Karadeniz kıyısında konumlanan Samsun kentinde yer almaktadır. Samsun'un ticaret yoğunluğu fazla olan en dinamik caddeleri Mecidiye Caddesi ve İstiklal Caddesi'dir. İstiklal Caddesi, bir uçta Yüzüncü Yıl Bulvarı'na bağlanan, diğer uçta Bağdat Caddesi ile kesişerek sonlanan kentin en uzun caddelerinden biridir. İlkadım İlçesi sınırları içinde yer alan bu cadde, gün boyu okula/işe gidip gelen öğrencilerin/çalışanların, alışverişe ve gezintiye çıkan insanların kullandığı yaya aksıdır. İstiklal Caddesi'nin, Osmaniye Caddesi'nden Lise Caddesi'ne kadar olan, yaklaşık 700 metre uzunluğundaki bölümü Çiftlik Caddesi olarak anılmaktadır. İstiklal Caddesi'nin bu bölümü çalışma alanı olarak belirlenmiştir. Kuzeybatı ve Güneydoğu yönünde, Gazi Caddesi ile 100. Yıl Bulvarına paralel konumlanan Çiftlik Caddesi, bu yollarla çok sayıda sokak aractlığıyla organik bir bağ kurmaktadır. Samsun'un en eski taşıt ve yaya trafik aksı olarak bilinmektedir (Şekil 1).

Kentin ilgi odağı olan Çiftlik Caddesi, alışveriş merkezi (AVM) projesi kapsamında yayalaştırılmış ve bina cepheleri yenilenmiştir. Ancak caddedeki değişimden sonra alışveriş hareketliliğinin azaldığını düşünen iş yeri sahiplerinin talebi üzerine, caddenin tekrar taşıt trafiğine açılması gündeme gelmiştir. Ayrıca cephe yenilemeyle ilgili kısa sürede birçok sorun yaşanması, kullanıcı memnuniyetini olumsuz yönde etkilemektedir. Bu nedenle çalışma, Çiftlik Caddesi'nin alışveriş potansiyelini artırmak, cadde kullanıcılarının daha rahat dolaşımını sağlamak ve caddenin çekiciliğini yükseltmek amaciyla gerçekleştirilen değişim projesinin yarattığ değeri ve cadde kullanıcıları üzerindeki etkisini tartışmak ve öneriler geliştirmek açısından önemlidir. 


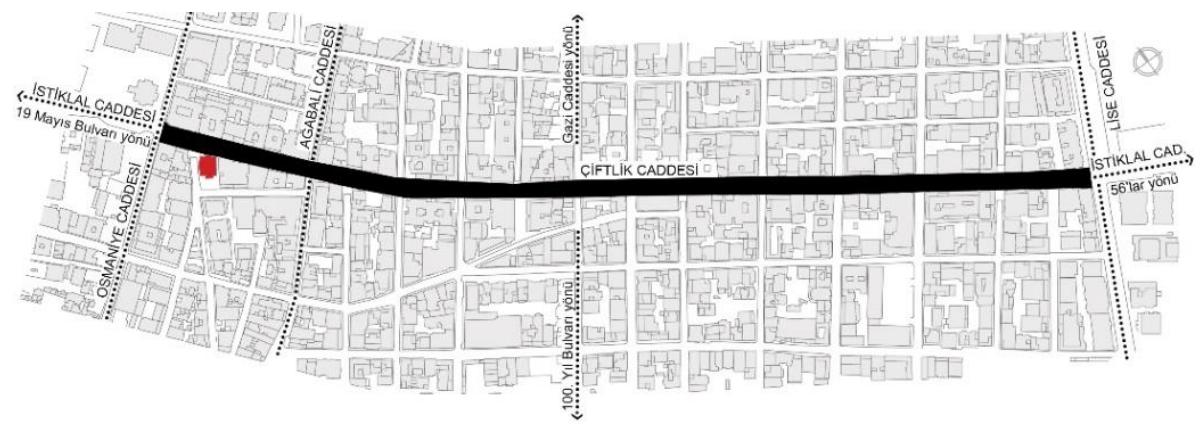

Şekil 1. Samsun Çiftlik Caddesi'nin konumu

Çalışmanın amac1; Çiftlik Caddesi'nde gerçekleşen değişimin kente estetik, sosyal ve ekonomik yönden ne düzeyde değer kattığının, caddenin yayalaştırılması ve bina cephelerinin yenilenmesiyle nasıl bir sonuç elde edildiğinin, kullanıcı konforunun ve memnuniyetinin hangi düzeyde olduğunun ve caddedeki değişimin sorunlara yol açıp açmadığının sorgulanmasıdır. Bu amaç doğrultusunda çalışmanın yöntemi, Samsun Çiftlik Caddesi'ndeki fiziki durumun incelenerek mekânsal özelliklerin belirlenmesi, cadde kullanıcılarının memnuniyet düzeyini ölçmek amacıyla anket yapılması, elde edilen bulguların tartışılması, değişime ilişkin mekânsal etkilerin saptanması ve mekânsal konforun yanı sıra, sosyal memnuniyeti arttırmak için caddeye ilişkin önerilerin geliştirilmesi şeklinde belirlenmiştir.

Samsun Çiftlik Caddesi özelinde yapılan ve caddelerdeki değişimde, yayalaştırma ve bina cephelerinin yenilenmesine odaklanan bu çalışma, durum tespiti ve anket olmak üzere iki aşamadan oluşmaktadır. Çalışmanın birinci aşamasında, Çiftlik Caddesi'nde yer alan binaların işlevleri, fiziki durumları ve caddedeki değişim araştırılmıştır. İkinci aşamada, caddeyi kullanan üç farklı denek grubunun caddedeki değişiklik ve yenilemeyle ilgili görüşleri anket tekniğiyle belirlenmiştir. Anket çalışmasında kullanıc1ların caddede bulunma nedenleri dikkate alınmış ve caddede çalışan, yaşayan ve caddeyi ziyaret edenlerin sayısına göre, $\% 95$ güvenirlik ve $\% 5$ hata payı gözetilerek örneklem sayıları saptanmıştır. Bu araştırmada gerçekleştirilen tüm anketler değerlendirmeye alınmıştır. Caddeyi en çok çalışanlar kullanmaktadır. Caddede yaşayanların sayısı ise azdır. Buna göre; caddede çalışan 63 kişi, caddeyi ziyaret eden 32 kişi, caddede yaşayan 25 kişi olmak üzere, rastlantısal olarak seçilen 120 kişiyle anket yapılmıştır. 


\section{Tespit Çalışmasına İlişkin Bulgular}

Çiftlik Caddesi, 19 Mayıs Bulvarı'nı 56'lar semtine bağlayan tek yönlü taşıt aksının ve toplu taşıma güzergâhının içinde yer almaktadır. Yayalaştırma çalışması yapılmadan önce bu cadde, yoğun yaya trafiğinin yanı sıra, yoğun taşıt trafiği de olan bir cadde olarak bilinmektedir (Şekil 2). Çiftlik Caddesi ile kesişen yolların taşıt trafiği tek yönlüdür. 19 Mayıs Bulvarı yönünden gelen taşıt trafiği, caddeyi kuzeybatı yönünde sınırlandıran Osmaniye Caddesi'nden 100. Yıl Bulvarı'na doğru yönlendirilmektedir. Caddeyi güneydoğu yönünde sinırlandıran Lise Caddesi'nin trafiği ise iki yönlüdür ve trafik akışı 56'lar semtine doğrudur. 100. Yıl Bulvar'na bağlanan Ağabali Caddesi'nden de Gazi Caddesi'ne doğru taşıt trafiğine izin verilmektedir.

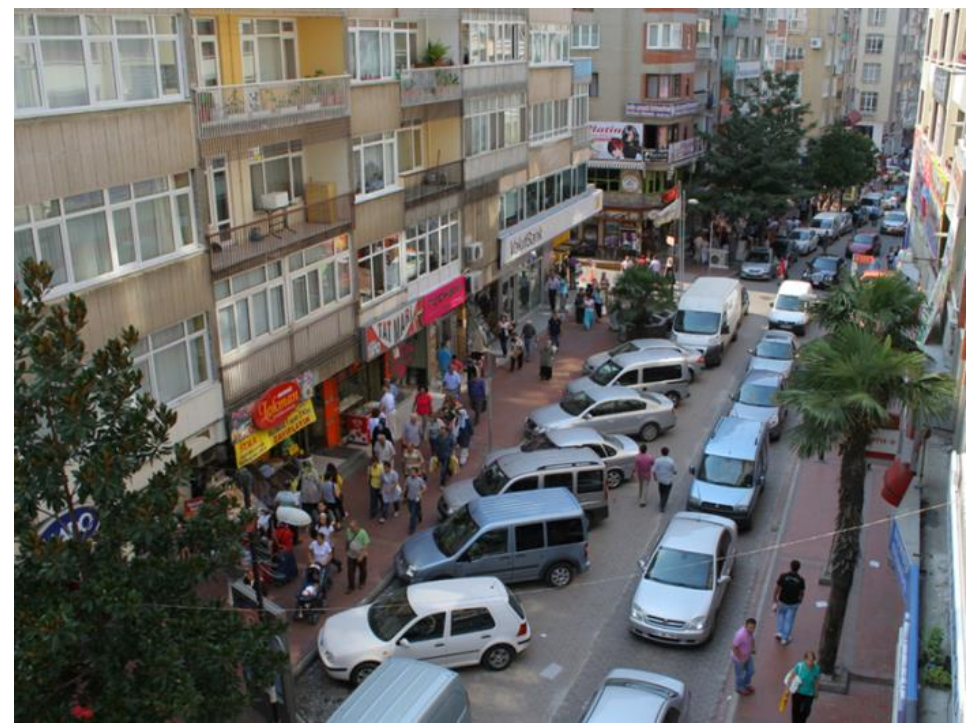

Şekil 2. Çiftlik Caddesi'nde taşıt yoğunluğu (Samsun Büyükşehir Belediyesi, 2019)

Çiftlik caddesi 1930'lara kadar ahşap evleri olan çiftliklerin bulunduğu bir caddeyken, 1930'lu yıllarda, 2-3 katlı ve bahçeli konutların yer aldığı bir aksa dönüşmüştür (Şekil 3). Caddenin eski dokusundan bugüne, yalnızca 19. yüzyılın sonralarında inşa edilmiş bir konak kalmıştır. Nüfus mübadelesi öncesinde Vasil Bey'e ait olan konak, 1936'dan 2000 yılına kadar Samsun'un ünlü tütün tüccarlarından Hakkı Tarhan tarafından kullanılmıştır (Kayıkçı, 2000). Daha sonra yenilenen ve işlev değişikliğine uğrayan bina, Elmas Hanım Konă̆ı olarak anılmaktadır (Şekil 4). 


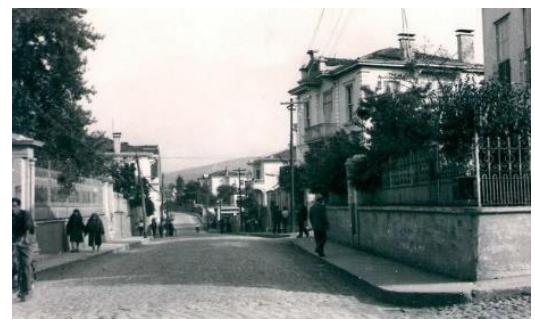

Şekil 3. 1930'lu yıllarda Çiftlik Caddesi ve Elmas Hanım Konağı - Osmaniye Caddesi girişi (Karadeniz Rumeli Dernekler Federasyonu, 2019)

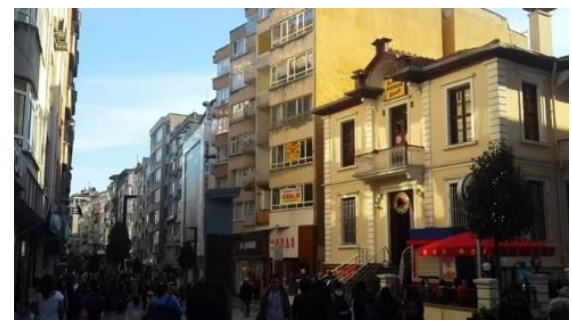

Şekil 4. Elmas Hanım Konağı ve bina Cephelerinin değişimden önceki durumu - Osmaniye Caddesi girişi (Samsun Web Rehberi, 2014)

Kent merkezinde bulunan ve kent halkının sürekli kullandığ 1 Çiftlik Caddesi, çok hareketli ve her zaman kalabalık bir alışveriş aksıdır. Caddeyi dikine kesen ve çok sayıda sokakla sınırlanan yapı adalarının oluşturduğu Çiftlik Caddesi'nin her iki arayüzünde 80 bina bulunmaktadır. Caddenin Alp Gündem Sokak ile kesiştiği köşede yer alan Elmas Hanım Konağı d1şındaki diğer binalar bitişik düzende konumlanmaktadır. Cephe hareketleri, yatay-düşey ve doluluk-boşluk oranları, pencere ve kapı düzenleri farklı olan bu binaların yükseklikleri 3-9 kat arasında değişmektedir (Şekil 5a, b). Genişliği 12.00 m-15.00 m aralığında değişen caddede, genelde 7 katlı binalar bulunmaktadır. Binaların zemin katlarında ticari amaçla kullanılan 122 mekân vardır. Bu mekânlarda, kent halkının tüm gereksinimlerini karşılayabileceği dokuz farklı işlev yer almaktadır. Alışveriş amaçlı düzenlenen caddede mağaza ve dükkânlar çoğunluktadır. Binaların üst katlarında farklı işlevler de mevcuttur. Üst katlar; konut (40 bina), konut + ticaret (36 bina), konut + sağlık (1 bina) ve ticaret (3 bina) olarak kullanılmaktadır (Şekil 6). 


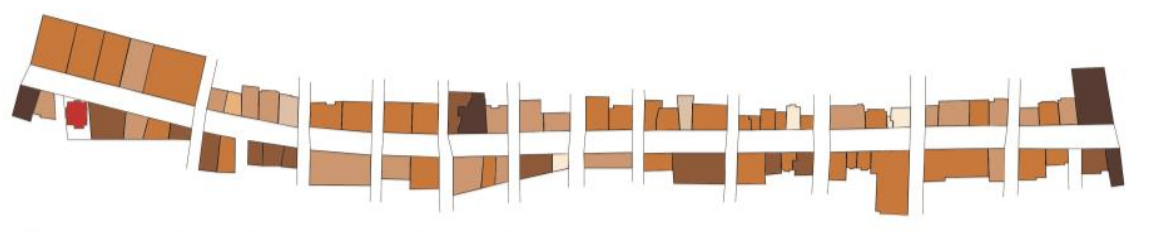

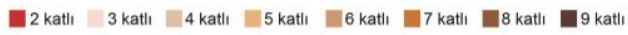

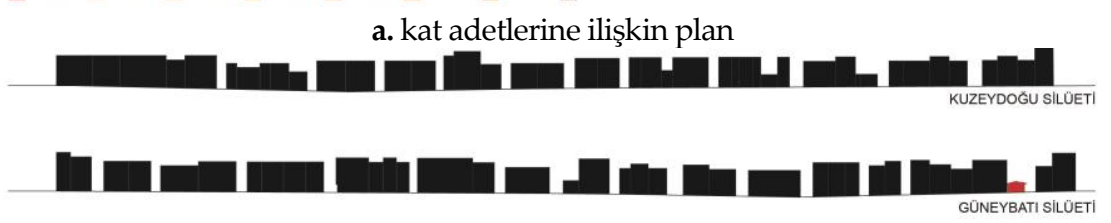

b. kat adetlerini ilişkin silüetler

Şekil 5. Çiftlik Caddesi'ndeki binaların kat adetleri

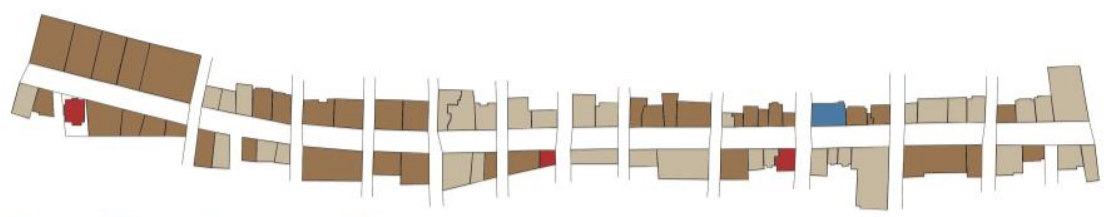

IKONUT ITICARI IEONUT+TICARI EKONUT+SAGLIK

Şekil 6. Çiftlik Caddesi'ndeki binaların işlevler

Çiftlik Caddesi, önceki dönemlerde çift yönlü taşıt trafiğine açıkken (Şekil 7), daha sonra caddenin her iki yönündeki kaldırımlar genişletilerek trafik tek yönlü düzenlenmiş ve caddenin bazı bölümlerinde otopark cepleri oluşturularak taşıtlara park etme olanağı sağlanmıştır. Cadde 2014 yılından sonra, AVM projesi kapsamında taşıt trafiğine kapatılarak yayalaştırılmıştır. Taşıt trafiğine kapatılan caddede, önce altyapı çalışmaları başlamış ve caddenin alt yapısı yenilenmiştir (Şekil 8).

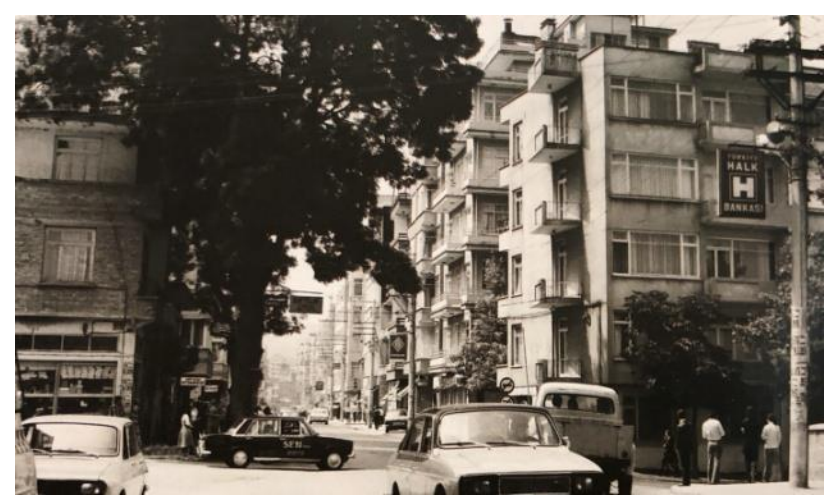

Şekil 7. Çiftlik Caddesi'nin çift yönlü taşıt trafiğine açık durumu Lise Caddesi girişi - 1975 yılı (İpek, Yılmaz ve Seylan, 2016) 


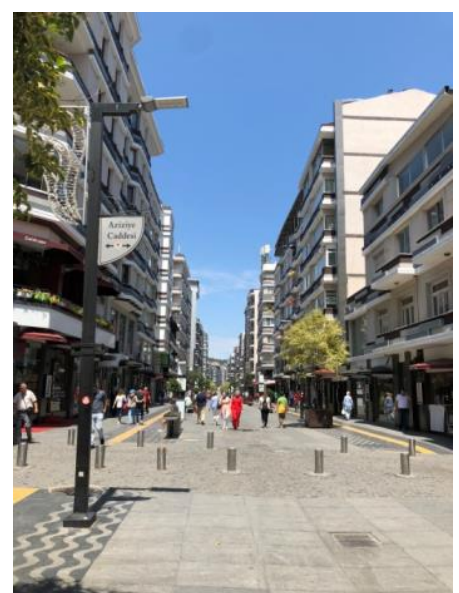

Şekil 8. Çiftlik Caddesi'nin yayalaştırılması

Çiftlik Caddesi'nin yayalaştırılması tamamlandıktan sonra, bitişik düzende konumlanan binaların cephelerinde yenileme çalışması başlamıştır. Caddede yer alan ticari mekânların zemin kat cephelerinde, bina girişleri ve vitrinler dışında kalan duvar yüzeylerine dış yalıtım yapılmış ve üzerine siyah dış cephe boyası uygulanmıştır. Zemin katların duvar yüzeylerinde koyu renk uygulama yapılması, vitrinlerin daha iyi algılanmasını sağlamaktadır. Bu kattaki duvar boşluklarının üzerinde, ticari mekân isimlerinin yazılı olduğu sabit tente biçiminde saçaklar bulunmaktadır. Bunun dışında, zemin kat cephe yüzeylerinde tabela yoktur. Bu uygulama, cephelerde oluşacak karmaşayı önlemekte ve zemin kat cephe düzleminde ortak bir dil oluşturmaktadır (Şekil 9).

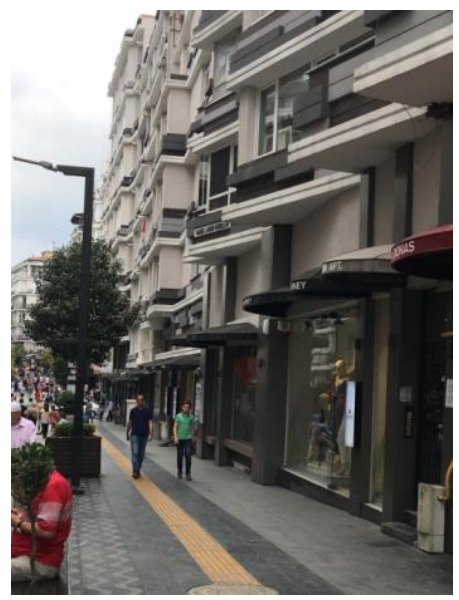

Şekil 9. Caddedeki binaların zemin kat cepheleri 
Caddedeki binaların üst katlarında geniş pencere yüzeyleri bulunmaktadır. Üst katlarda da dış yalıtım uygulanmıştır. Genelde cephelerde yatay doku etkilidir. Bu doku, duvar boşlukları üzerinde cepheyi sürekli dolanan beyaz kat silmesi ve bunun üzerine üst üste dizilmiş farklı kalınlıklarda $(5 \mathrm{~cm}-25 \mathrm{~cm})$ ve renklerde (siyah, gri ve kahverengi) EPS bloklarla oluşturulmuştur. Bu düzen her katta tekrar etmektedir (Şekil 10). EPS blokların eğri yüzeyler, balkonlar, duvar boşlukları gibi farklı cephe biçimlenişlerinin uygulandığı bölümlerde cepheyle uyum sağlamadığı görülmektedir. Özellikle bitişik düzende konumlanan binaların birleştiği bölümlerde, bina kat yüksekliklerinin farklı olması nedeniyle EPS bloklar aynı düzlemde bitirilememiştir. Bu durum, estetik olmayan yüzeyler ve ayrıntılar oluşturmuştur (Şekil 11).

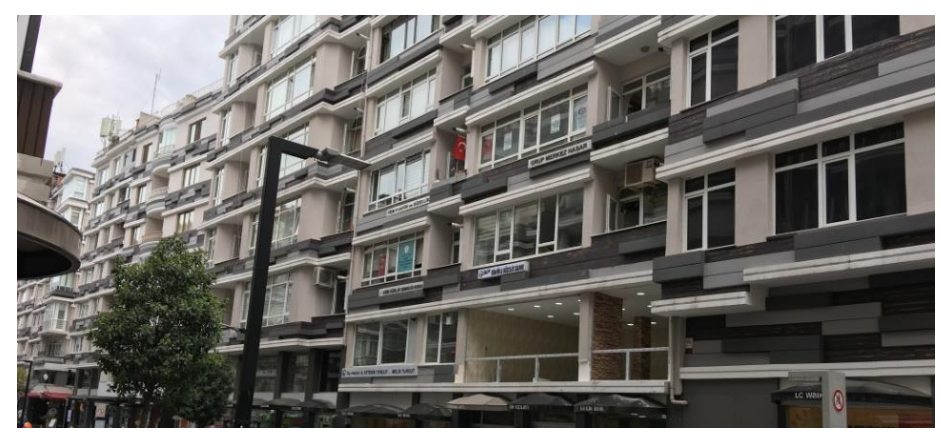

Şekil 10. Çiftlik Caddesi'ndeki bina cephelerin değişimi

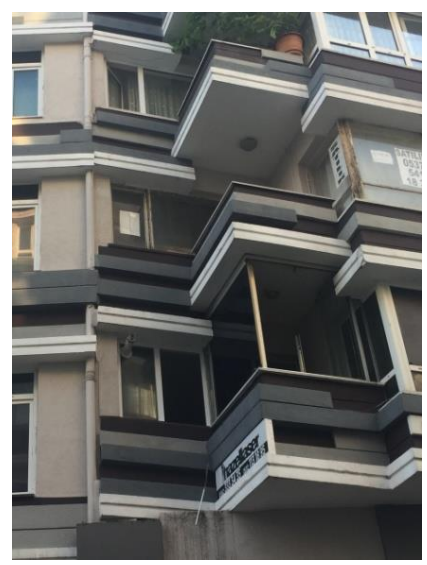

Şekil 11. Bina cephelerindeki uygulamada yüzey ve ayrıntı sorunları 


\section{Anket Çalışmasına İlişkin Bulgular}

Çalışmanın bu bölümünde, anketten elde edilen bulgular değerlendirilmektedir. Anketin ilk bölümünde katılımclara cinsiyet, yaş, eğitim düzeyi ve caddede bulunma nedenleri sorulmuştur (Tablo 1). Ankete katılanların \%53,4'ünü kadınlar, \%46,6'sını erkekler oluşturmaktadır. Caddede çalışanların oranı $\% 52,6$ 'dır. Katılımcıların \%56'sı 30-49 yaş grubundadır. Lise mezunlarının oranı \%42,5 iken, İlköğretim/Ortaokul mezunlarının oranı $\% 15,8$ 'dir. Çevre algısında cinsiyet ve yaş farklılığının, eğitim düzeyinin etkisinin olup olmadığının belirlenmesi için, farklı gruplara caddenin değişik bölgelerinde anket uygulanmıştır. Anket çalışmasında katılımcıların caddenin eski durumunu bilmeleri önemsendiği için, 18 yaş altı bireylerin ankete katılması tercih edilmemiştir. Katılımcıların cinsiyet oranlarının birbirine yakın olmasına özen gösterilmiştir.

Tablo 1. Ankete katılanların caddede bulunma nedenlerine göre cinsiyet, yaş ve eğitim düzeyi

\begin{tabular}{|c|c|c|c|c|c|c|c|c|c|}
\hline & & \multicolumn{2}{|l|}{ Caddede } & \multicolumn{2}{|l|}{ Caddede } & \multicolumn{2}{|l|}{ Caddeyi } & \multirow[b]{2}{*}{ Toplam } & \multirow[b]{2}{*}{$\%$} \\
\hline & & Yaşayan & $\%$ & Çalışan & $\%$ & Ziyaret Eden & $\%$ & & \\
\hline \multirow[t]{2}{*}{ Cinsiyet } & Kaden & 16 & 13,3 & 32 & 26,8 & 16 & 13,3 & 64 & 53,4 \\
\hline & Erkek & 9 & 7,5 & 31 & 25,8 & 16 & 13,3 & 56 & 46,6 \\
\hline \multirow[t]{3}{*}{ Yaş } & $18-29$ yaş & 4 & 3,3 & 16 & 13,3 & 6 & 5,0 & 26 & 21,6 \\
\hline & $30-49$ yaş & 12 & 10,0 & 40 & 33,5 & 15 & 12,5 & 67 & 56,0 \\
\hline & 50 ve üzeri yaş & 9 & 7,5 & 7 & 5,8 & 11 & 9,1 & 27 & 22,4 \\
\hline Eğitim & Illköğretim/Ortaokul & 3 & 2,5 & 13 & 10,8 & 3 & 2,5 & 19 & 15,8 \\
\hline \multirow[t]{5}{*}{ Düzeyi } & Lise & 13 & 10,8 & 25 & 20,9 & 13 & 10,8 & 51 & 42,5 \\
\hline & Ön Lisans & 4 & 3,3 & 12 & 10,1 & 4 & 3,3 & 20 & 16,7 \\
\hline & Lisans & 3 & 2,5 & 9 & 7,5 & 10 & 8,3 & 22 & 18,3 \\
\hline & Lisansüstü & 2 & 1,7 & 4 & 3,3 & 2 & 1,7 & 8 & 6,7 \\
\hline & TOPLAM & 25 & 20,8 & 63 & 52,6 & 32 & 26,6 & 120 & 100 \\
\hline
\end{tabular}

Anketin ikinci bölümünde, Çiftlik Caddesi'ndeki değişimin etkilerini anlayabilmek için, katılımcılara sırasıyla; caddedeki değişimin gerekliliği, değişimin caddeye huzur ve ferahlık getirip getirmediği, caddenin yayalaştırilmasındaki memnuniyet, bina cephelerinde estetik, bina cephelerinin birbirine benzemesi ve bina cephelerinde yangın güvenliği konularında 6 adet 3’lü Likert ölçeğine göre (katılıyorum, kararsızım, katılmıyorum) soru sorulmuştur. Bu sorularla Çiftlik Caddesi'nde yaşayanlar, çalışanlar ve ziyaretçiler arasında memnuniyet algısındaki farklılıklar analiz edilmeye çalışılmıştır. Caddede bulunma durumuna göre bir sıralama yapıldığında, caddede en çok yaşayanların bulundukları, daha sonra çalışanların geldiği, ziyaretçilerin ise daha kısa süreli ve seyrek olarak caddeyi kullandıkları için her grup ayrı değerlendirilmiş ve cinsiyet ve yaş farklılığının, eğitim düzeyinin yanıtlara ne şekilde yansıdığı araştırılmıştır. Bunun için anketten elde 
edilen veriler, SPSS programında One-Way ANOVA analiz modeli kullanılarak karşılaştırılmıştır. Çiftlik Caddesi'nde bulunanların caddedeki değişimle ilgili görüş, tercih ve isteklerinin belirlenmesi amaciyla yapılan ankette sözlü bildirimler de alınmış ve caddede yapılan yeni uygulamanın olumlu ve olumsuz yönleri saptanmaya çalışılmıştır.

Caddede bulunma nedenlerine göre, "caddedeki değişimin gerekli bulunması" ve "caddenin yayalaştırılmasından memnuniyet duyulması" durumları için gruplar arasında anlamlı farklılıklar olmadığ 1 (p>0,05), "caddedeki değişimin huzur ve ferahlık hissettirmesi" ve "bina cephelerinin estetik bulunması, birbirine benzemesinin olumlu karşılanması ve yangın güvenliği açısından uygun bulunması" durumları için ise anlamlı farklılıklar bulunduğu $(p<0,05)$ belirlenmiştir. Karşılaştırılan grupların ortalamaları arasındaki farklara bakıldığında, caddede yaşayanlarla diğer gruplar arasında ikili anlamlı farklılıklar vardır (Tablo 2).

Tablo 2. Caddede bulunma nedenlerine göre değerlendirme

\begin{tabular}{|c|c|c|c|c|c|c|c|}
\hline & & & $\begin{array}{r}\text { Kareler } \\
\text { Toplamı }\end{array}$ & $\begin{array}{r}\text { Serbestlik } \\
\text { Derecesi }\end{array}$ & $\begin{array}{r}\text { Kareler } \\
\text { Ortalamas1 }\end{array}$ & $\mathbf{F}$ & $\mathrm{p}$ \\
\hline \multirow{3}{*}{1} & \multirow{3}{*}{$\begin{array}{r}\text { Caddedeki değişimi gerekli } \\
\text { buluyor musunuz? }\end{array}$} & Gruplar arası &, 543 & 2 & ,272 & 343 & 710 \\
\hline & & Grup içi & 92,624 & 117 & ,792 & & \\
\hline & & Toplam & 93,167 & 119 & & & \\
\hline \multirow{3}{*}{2} & \multirow{3}{*}{$\begin{array}{r}\text { Cadde size huzur ve ferahlik } \\
\text { hissettiriyor mu? }\end{array}$} & Gruplar arası & 7,797 & 2 & 3,898 & 4,096 & 019 \\
\hline & & Grup içi & 111,370 & 117 & ,952 & & \\
\hline & & Toplam & 119,167 & 119 & & & \\
\hline \multirow{3}{*}{3} & \multirow{3}{*}{$\begin{array}{l}\text { Caddenin yayalaştırılmasından } \\
\text { memnun musunuz? }\end{array}$} & Gruplar arası & 1,011 & 2 &, 506 &, 577 &, 563 \\
\hline & & Grup içi & 102,581 & 117 & 877 & & \\
\hline & & Toplam & 103,592 & 119 & & & \\
\hline \multirow{3}{*}{4} & \multirow{3}{*}{$\begin{array}{l}\text { Bina cephelerini estetik buluyor } \\
\text { musunuz? }\end{array}$} & Gruplar arası & 16,534 & 2 & 8,267 & 9,360 &, 000 \\
\hline & & Grup içi & 103,333 & 117 &, 883 & & \\
\hline & & Toplam & 119,867 & 119 & & & \\
\hline \multirow{3}{*}{5} & Bina cephelerinin birbirine & Gruplar arası & 10,046 & 2 & 5,023 & 5,713 &, 004 \\
\hline & benzemesini olumlu karşılıyor & Grup içi & 102,879 & 117 & 879 & & \\
\hline & musunuz? & Toplam & 112,925 & 119 & & & \\
\hline \multirow{3}{*}{6} & Bina cephelerini yangin & Gruplar arası & 3,830 & 2 & 1,915 & 5,077 &, 008 \\
\hline & güvenliği açısından uygun & Grup içi & 44,136 & 117 &, 377 & & \\
\hline & buluyor musunuz? & Toplam & 47,967 & 119 & & & \\
\hline
\end{tabular}

Çiftlik Caddesi'ndeki değişime ilişkin verilen yantların ortalamaları, anketteki soru sırası dikkate alınarak Tablo 3'de özetlenmektedir. Tüm sorulara verilen yanıtlar incelendiğinde, caddedeki değişime katıldıklarını bildirenlerden sayısı fazla olanların caddede bulunma nedeni, cinsiyet ve yaş grubu aynıdır. Bu tespite göre, caddede çalışan, kadın ve 18-29 yaş grubundaki katılımclar, diğerlerine göre caddedeki değişimi daha yüksek oranda desteklemektedir. Eğitim durumunda ise, 1. ve 2. sorularda Ön Lisans mezunları, 3., 4., 5. ve 6. sorularda İlköğretim/Ortaokul mezunları öne çıkmaktadır. Caddede yaşayan, erkek, 50 ve üstü yaş grubu ve Ön Lisans mezunu katılımcıların ise, caddedeki değişimi destekleme oranı düşüktür. 
Anket sonuçlarından elde edilen bulgular Tablo 4'de verilmektedir. Bu sonuçlara ilişkin oransal bir değerlendirme yapıldığında, katılımcların $\% 68,3$ ü caddedeki değişimi gerekli bulurken, \%27,5'i gerekli olmadığını düşünmektedir. Katılımcıların \%4,2'si ise kararsızdır. Caddedeki değişimi gerekli bulanlar arasında kadınların oranı daha yüksektir. Caddeyi kullananların çoğunluğu değişimi desteklemektedir. Ancak caddede yaşayanların destekleme oranı diğerlerine göre düşüktür. Buna neden olarak, cephe yenileme maliyeti gösterilebilir. 18-29 yaş grubu katılımcıların \%84,6'sı caddedeki değişimi gerekli bulurken, diğer yaş gruplarında oran düşmektedir. Dolayısıyla genç cadde kullanıcıları değişime daha sıcak bakmaktadır. Genelde eğitim gruplarının destekleme oranları yüksektir. Bu oran, İlköğretim/Ortaokul ve Ön Lisans mezunlarında \%80'nin üzerine çımaktadır. Lisans eğitimini tamamlamış katılımcıların \%50'si ise aynı fikirde değildir.

Tablo 3. Çiftlik Caddesi'ndeki değişime ilişkin verilen yanıtların ortalamaları

\begin{tabular}{|c|c|c|c|c|c|c|c|}
\hline \multirow{2}{*}{\multicolumn{2}{|c|}{ Ankete Katılanların Özellikleri }} & \multicolumn{6}{|c|}{ Ortalama } \\
\hline & & 1 & 2 & 3 & 4 & 5 & 6 \\
\hline \multirow[t]{3}{*}{ Caddede Bulunma Nedeni } & Caddede Yaşayan & 1,70 & 2,56 & 1,74 & 2,70 & 2,56 & 2,81 \\
\hline & Caddede Çalıșan & 1,53 & 1,93 & 1,55 & 1,77 & 1,83 & 2,38 \\
\hline & Caddeyi Ziyaret Eden & 1,58 & 1,97 & 1,73 & 1,97 & 1,94 & 2,39 \\
\hline \multirow[t]{2}{*}{ Cinsiyet } & Erkek & 1,79 & 2,25 & 1,96 & 2,14 & 2,07 & 2,55 \\
\hline & Kadin & 1,41 & 1,94 & 1,36 & 1,94 & 1,98 & 2,42 \\
\hline \multirow[t]{3}{*}{ Yaş } & $18-29$ yaș & 1,31 & 1,85 & 1,23 & 1,69 & 1,69 & 2,23 \\
\hline & $30-49$ yaş & 1,63 & 2,07 & 1,73 & 2,07 & 2,07 & 2,51 \\
\hline & 50 ve üstï & 1,74 & 2,33 & 1,81 & 2,26 & 2,22 & 2,67 \\
\hline \multirow[t]{5}{*}{ Eğitim Düzeyi } & İköğretim/Ortaokul & 1,33 & 1,89 & 1,44 & 1,56 & 1,78 & 2,33 \\
\hline & Lise & 1,58 & 2,19 & 1,63 & 2,19 & 2,13 & 2,50 \\
\hline & Ön Lisans & 1,26 & 1,84 & 1,53 & 1,84 & 1,79 & 2,47 \\
\hline & Lisans & 2,04 & 2,30 & 1,96 & 2,22 & 2,13 & 2,57 \\
\hline & Lisansüstï & 1,63 & 1,75 & 1,50 & 2,00 & 2,13 & 2,50 \\
\hline
\end{tabular}

Katılımciların \%50'si, caddenin engellilerin kullanımına uygun olmadığ1 yönünde sözlü bildirimde bulunmuştur. Caddeyi kullananların bir bölümü bina cephelerinin birbirine benzemesi ve caddenin taşıt trafiğine kapatılması konularında rahatsızlık duyduklarını belirtirken, diğer bölümü cadde yenileme maliyetinin yükssek olmasından rahatsızdır. Katılımcıların çoğunluğu caddede sanat panolanı, güncel afişler, sergiler bulunmasını ve sokak müzisyenlerinin olmasın istemektedir.

Katılımcıların \%68,3'ü yayalaştırmadan memnun olmasına karşın, \%30,8'i yayalar için yapılan düzenlemeden memnuniyet duymamaktadır. Caddedeki değişimden memnun olanların oranıyla yayalaştırmadan memnun olanların oranı aynıdır. Bir kişinin karasız olduğu belirlenmiştir. Katılımclların üçte biri, caddenin tekrar taşıt trafiğine açlmasını istemektedir. Bunların arasında caddede çalışanlar da bulunmaktadır. Özellikle iş yeri 
sahipleri, alışveriş hareketliliğinin azalması ve servis olanağının ortadan kalkması nedeniyle yayalaştırmadan memnun olmadıklarını sözlü olarak bildirmişlerdir. Kadın katılımcıların caddenin yayalaştırılmasından daha fazla memnun olduğu anlaşılmaktadır. Yaş grubuna göre dağılımda da, 1829 yaş grubunun \%88,5'i yayalaştırmadan memnundur. Buna neden olarak, yayalaştırmayla birlikte caddede daha rahat alışveriş yapma ve gezme ortamı oluşması gösterilebilir. Eğitim durumuna göre, İlköğretim/Ortaokul ve Ön lisans eğitimini tamamlamış katılımcıların yayalaştırmadan memnun olma oranının çok yüksek olduğu görülmektedir.

Katılımcıların \%45,8'i caddedeki değişimin caddeye huzur ve ferahlık getirdiğini, \%54,2'si ise sıkıntılı ve kasvetli bir ortam yarattı̆ını düşünmektedir. 50 ve üstü yaş grubu katılımcıların çoğunluğu olumsuz görüş bildirmiştir. Erkek katılımcılar da aynı görüşü paylaşırken, kadınların görüşü olumludur. İlköğretim/Ortaokul ve Ön Lisans mezunlarının çoğunluğu, caddede huzur ve ferahlık hissetmektedir. Buna karşın, Lisans mezunlarının $\% 68$,2'si caddeyi sıkıntılı ve kasvetli bulmaktadır. Caddeyi kullananlar arasında da görüş farklılıkları vardır. Caddede çalışanların \%55,6'sı olumlu görüş bildirirken, caddede yaşayanların \%80'inin görüşü olumsuzdur. Elde edilen bu verilere göre, caddedeki algının cinsiyete, yaşa, eğitim durumuna ve caddeyi kullanma durumuna göre farklılık gösterdiği belirlenmiştir.

Tablo 4. Çiftlik Caddesi'ndeki değişime ilişkin değerlendirme (oransal)

\begin{tabular}{|c|c|c|c|c|c|c|c|c|c|c|c|c|c|}
\hline \multirow{3}{*}{\multicolumn{2}{|c|}{ Ankete Katılanların Özellikleri }} & \multicolumn{2}{|c|}{ Katiliyorum } & \multicolumn{2}{|c|}{ Kararsizim } & \multicolumn{2}{|c|}{ Katılmiyorum } & \multicolumn{2}{|c|}{ Katiliyorum } & \multicolumn{2}{|c|}{ Kararsızım } & \multicolumn{2}{|c|}{ Katılmiyorum } \\
\hline & & $\mathrm{n}$ & $\%$ & $\mathrm{n}$ & $\%$ & $\mathrm{n}$ & $\%$ & $\mathrm{n}$ & $\%$ & $\mathrm{n}$ & $\%$ & $\mathrm{n}$ & $\%$ \\
\hline & & \multicolumn{6}{|c|}{ Caddedeki değișimin gerekli bulunması } & \multicolumn{6}{|c|}{$\begin{array}{r}\text { Caddedeki değişimin huzur ve ferahlık } \\
\text { hissettirmesi }\end{array}$} \\
\hline \multicolumn{14}{|c|}{ Caddede Bulunma Nedeni } \\
\hline & Caddede Çalışanlar & 44 & 69,8 & 3 & 4,8 & 16 & 25,4 & 35 & 55,6 & 0 & 0,0 & 28 & 44.4 \\
\hline & ddeyi Ziyaret Edenler & 22 & 68,8 & 1 & 3,1 & 9 & 14,3 & 15 & 46,9 & 0 & 0,0 & 17 & 53.1 \\
\hline & Caddede Yaşayanlar & 16 & 64,0 & 1 & 4,0 & 8 & 32,0 & 5 & 20,0 & 0 & 0,0 & 20 & 80.0 \\
\hline \multirow[t]{2}{*}{ Cinsiyet } & Kadın & 50 & 78,1 & 1 & 1,6 & 13 & 20,3 & 34 & 53,1 & 0 & 0,0 & 30 & 46.9 \\
\hline & Erkek & 32 & 57,1 & 4 & 7,1 & 20 & 35,7 & 21 & 37,5 & 0 & 0,0 & 35 & 62.5 \\
\hline \multirow[t]{3}{*}{ Yaş } & 18-29 Yaş & 22 & 84,6 & 0 & 0,0 & 4 & 15,4 & 15 & 57,7 & 0 & 0,0 & 11 & 42.3 \\
\hline & 30-49 Yaş & 44 & 65,7 & 3 & 4,5 & 20 & 29,8 & 32 & 47,8 & 0 & 0,0 & 35 & 52.2 \\
\hline & 50 Ve Üstü Yaş & 16 & 59,3 & 2 & 7,4 & 9 & 33,3 & 8 & 29,6 & 0 & 0,0 & 19 & 70.4 \\
\hline Eğitim & İlköğretim/Ortaokul & 15 & 83,3 & 0 & 0,0 & 3 & 16,7 & 10 & 55,6 & 0 & 0,0 & 8 & 44.4 \\
\hline \multirow[t]{5}{*}{ Düzeyi } & Lise & 35 & 67,3 & 1 & 1,9 & 16 & 30,8 & 22 & 42,3 & 0 & 0,0 & 30 & 57.7 \\
\hline & Ön Lisans & 17 & 89,4 & 1 & 5,3 & 1 & 5,3 & 11 & 57,9 & 0 & 0,0 & 8 & 42.1 \\
\hline & Lisans & 10 & 45,5 & 2 & 9,0 & 10 & 45,5 & 7 & 31,8 & 0 & 0,0 & 15 & 68.2 \\
\hline & Lisansüstü & 5 & 55,6 & 1 & 11,1 & 3 & 33,3 & 5 & 55,6 & 0 & 0,0 & 4 & 44.4 \\
\hline & Toplam & 82 & 68,3 & 5 & $\mathbf{4 , 2}$ & 33 & 27,5 & 55 & 45,8 & 0 & 0,0 & 65 & 54.2 \\
\hline
\end{tabular}




\begin{tabular}{|c|c|c|c|c|c|c|c|c|c|c|c|c|}
\hline & \multicolumn{7}{|c|}{$\begin{array}{r}\text { Caddenin yayalaştırilmasından } \\
\text { memnuniyet duyulması }\end{array}$} & \multicolumn{5}{|c|}{ Bina cephelerinin estetik bulunması } \\
\hline \multicolumn{13}{|l|}{ Caddede Bulunma Nedeni } \\
\hline Caddede Çalıșanlar & 45 & 71,4 & 1 & 1,6 & 17 & 27,0 & 38 & 60,3 & 0 & 0,0 & 25 & 39,7 \\
\hline Caddeyi Ziyaret Edenler & 20 & 62,5 & 0 & 0,0 & 12 & 37,5 & 15 & 46,9 & 0 & 0,0 & 17 & 53,1 \\
\hline Caddede Yaşayanlar & 17 & 68,0 & 0 & 0,0 & 8 & 32,0 & 5 & 20,0 & 0 & 0,0 & 20 & 80,0 \\
\hline Kadın & 53 & 82,8 & 1 & 1,6 & 10 & 15,6 & 34 & 53,1 & 0 & 0,0 & 30 & 46,9 \\
\hline Erkek & 29 & 51,8 & 0 & 0,0 & 27 & 48,2 & 24 & 41,4 & 0 & 0,0 & 34 & 58,6 \\
\hline 18-29 Yaş & 23 & 88,5 & 0 & 0,0 & 3 & 11,5 & 17 & 65,4 & 0 & 0,0 & 9 & 34,6 \\
\hline 30-49 Yaş & 42 & 62,7 & 1 & 1,5 & 24 & 35,8 & 31 & 46,3 & 0 & 0,0 & 36 & 53,7 \\
\hline 50 Ve Üstü Yaş & 17 & 63,0 & 0 & 0,0 & 10 & 37,0 & 10 & 37,0 & 0 & 0,0 & 17 & 63,0 \\
\hline İlköğretim/Ortaokul & 14 & 77,8 & 0 & 0,0 & 4 & 22,2 & 13 & 72,2 & 0 & 0,0 & 5 & 27,8 \\
\hline \multirow{6}{*}{$\begin{array}{r}\text { Lise } \\
\text { Ön Lisans } \\
\text { Lisans } \\
\text { Lisansüstï } \\
\text { Toplam }\end{array}$} & 35 & 67,3 & 1 & 1,9 & 16 & 30,8 & 21 & 40,4 & 0 & 0,0 & 31 & 59,6 \\
\hline & 16 & 84,2 & 0 & 0,0 & 3 & 15,8 & 11 & 57,9 & 0 & 0,0 & 8 & 42,1 \\
\hline & 11 & 50,0 & 0 & 0,0 & 11 & 50,0 & 9 & 40,9 & 0 & 0,0 & 13 & 59,1 \\
\hline & 6 & 66,7 & 0 & 0,0 & 3 & 33,3 & 4 & 44,4 & 0 & 0,0 & 5 & 55,6 \\
\hline & 82 & 68,3 & 1 & 0,9 & 37 & 30,8 & 58 & 48,3 & $\mathbf{0}$ & 0,0 & 62 & 51,7 \\
\hline & & \multicolumn{6}{|c|}{$\begin{array}{r}\text { Bina cephelerinin birbirine } \\
\text { benzemesinin uygun bulunmasi }\end{array}$} & \multicolumn{5}{|c|}{$\begin{array}{r}\text { Bina cephelerinin yangın güvenliği } \\
\text { açısmdan uygun bulunması }\end{array}$} \\
\hline \multicolumn{13}{|l|}{ Caddede Bulunma Nedeni } \\
\hline Caddede Çalışanlar & 31 & 49,2 & 7 & 11,1 & 25 & 39,7 & 5 & 7,9 & 28 & $\mathbf{4 4 , 4}$ & 30 & 47,6 \\
\hline \multirow{2}{*}{$\begin{array}{r}\text { Caddeyi Ziyaret Edenler } \\
\text { Caddede Yaşayanlar }\end{array}$} & 15 & 46,9 & 0 & 0,0 & 17 & 53,1 & 4 & 12,5 & 11 & 34,4 & 17 & 53,1 \\
\hline & 7 & 28,0 & 0 & 0,0 & 18 & 72,0 & 0 & 0,0 & 8 & 32,0 & 17 & 68,0 \\
\hline Cinsiyet Kadın & 31 & 48,4 & 2 & 3,2 & 31 & 48,4 & 4 & 6,3 & 32 & 50,0 & 28 & 43,7 \\
\hline Erkek & 22 & 39,3 & 5 & 8,9 & 29 & 51,8 & 5 & 8,9 & 15 & 26,8 & 36 & 64,3 \\
\hline 18-29 Yaș & 17 & 65,4 & 0 & 0,0 & 9 & 34,6 & 5 & 19,2 & 11 & 42,3 & 10 & 38,5 \\
\hline 30-49 Yaş & 26 & 38,8 & 6 & 9,0 & 35 & 52,2 & 3 & 4,5 & 29 & 43,3 & 35 & 52,2 \\
\hline 50 Ve Üstü Yaş & 10 & 37,0 & 1 & 3,7 & 16 & 59,3 & 1 & 3,7 & 7 & 25,9 & 19 & 70,4 \\
\hline İlköğretim/Ortaokul & 8 & 44,4 & 0 & 0,0 & 10 & 55,6 & 2 & 11,1 & 10 & 55,6 & 6 & 33,3 \\
\hline Düzeyi & 23 & 44,2 & 1 & 1,9 & 28 & 53,8 & 5 & 9,6 & 16 & 30,8 & 31 & 59,6 \\
\hline Ön Lisans & 11 & 57,9 & 2 & 10,5 & 6 & 31,6 & 0 & 0,0 & 11 & 57,9 & 8 & 42,1 \\
\hline Lisans & 9 & 40,9 & 2 & 9,1 & 11 & 50,0 & 1 & 4,5 & 8 & 36,4 & 13 & 59,1 \\
\hline Lisansüstüi & 2 & 22,2 & 2 & 22,2 & 5 & 55,6 & 1 & 11,1 & 2 & 22,2 & 6 & 66,7 \\
\hline Toplam & 53 & 44,2 & 7 & 5,8 & 60 & 50,0 & 9 & 7,5 & 47 & 39,2 & 64 & 53,3 \\
\hline
\end{tabular}

Katılımcların \%48,3'ü yenilenen bina cephelerini estetik bulurken, $\% 51,7$ 'si estetik olmadığını düşünmektedir. Bina cephelerinin estetik olmadığını düşünenlerin oranı, caddede yaşayanların verdiği yanıtlarda (\%80) yükselmektedir. Caddede çalışanların çoğunluğu ise, yenilenen bina cephelerini estetik bulmaktadır. Kadınlarla erkekler birbirlerinden farklı görüştedir. Yaşa göre dağılımda, 18-29 yaş grubu ile diğer yaş grupları arasından da farklılık vardır. Eğitim durumuna göre, İlköğretim/Ortaokul ve Ön Lisans mezunları dışındaki katılımcıların cephe estetiğiyle ilgili düşünceleri olumsuzdur.

Değişen bina cephelerinin birbirine benzemesini katılımcların \%44,2'si olumlu karşılarken, \%50'si olumsuz bulmuştur. Katılımcların $\% 5,8$ 'i ise kararsızdır. Caddeyi ziyaret edenlerin ve caddede yaşayanların çoğunluğu bina cephelerinin birbirine benzemesinden memnun değildir. $\mathrm{Bu}$ oran, caddede çalışanlarda \%39,7'ye düşerken, caddede yaşayanlarda \%72'ye yükselmektedir. Kadınlarda memnuniyet oran \%50 sınırındadır. Erkeklerin çoğunluğu ise olumlu karşılamamaktadır. Yaşa göre dağllımda, 18-29 yaş arası katılımcılardan \%65,4'ünün düşüncesi olumludur. Genelde 
bu yaş grubunun caddede yapılan çalışmalardan memnun olduğu görülmektedir. Eğitim durumuna göre, Ön Lisans mezunlarının dışındaki katılımcılar, cephelerdeki benzerliğe sıcak bakmamaktadır. Katılımcıların $\% 50$ 'den fazlası, yenilenen bina cephelerinde bozulmalar ve hasarlar olduğu yönünde sözlü bildirimde bulunmuştur. Cephelerin birbirine benzemesinin estetik algıyı olumsuz yönde etkilediği söylenebilir.

Bina cephelerinin yenilenmesinde EPS ürünlerin kullanıldığı Çiftlik Caddesi'ndeki binalarda, katılımcıların \%7,5'i cepheleri yangın güvenliği açısından uygun bulurken, \%53,3'ü uygun olmadığ 1 görüşündedir. Bu konuda kararsız olanların oranı $(\% 39,2)$ yüksektir. Uygun bulmayanların yar1sı, bina cephelerinde EPS ürünler kullanıldığını sözlü olarak belirtmiştir. Bina cephelerini yangın güvenliği açısından uygun bulmayan erkeklerin sayısı kadınlara göre daha fazladır. Yaşa göre dağılımda, 50 ve üstü yaş grubundaki katılımcıların büyük çoğunluğu bina cephelerini yangın güvenliği açısından uygun bulmamaktadır. Eğitime göre dağılımda da tüm gruplar uygun olmadığ1 görüşünde birleşmiştir.

\section{Çiftlik Caddesindeki Değişime İlişkin Mekânsal Etkilerin Tartışılması}

Çiftlik Caddesi, tarihsel süreç içinde farklı morfolojik yapılarla biçimlenmiş ve kent içinde özgün bir cadde karakteri oluşmuştur. Geçmişte çiftliklerin siralandığı bir aks olan bu caddede, 1930'lu yıllarda 2-3 katlı ve bahçeli konutlarla farklı bir kentsel doku ortaya çımıştır. Daha sonra, bu konutlar yıkılarak, cadde boyunca bitişik düzende çok katlı binalar inşa edilmiştir. Bu dönemde caddenin hem imar durumunda hem de dokusunda büyük bir farklılık olmuş, yoğunluğu artmış ve işlevi değişmiştir. Konut ve ticaret işlevlerinin birlikte yer aldığı caddede, konutlar yerini ticarete bırakmıştır. Caddedeki binaların, yenilemeden önce birbirinden farklı cephe kuruluşuna sahip oldukları bilinmektedir. Uzun bir süreçte gelişen cephelerdeki farklı dil, fiziksel bir bellek oluşturmuş ve caddenin mekânsal kimliğini belirlemiştir. Bu süreçte cadde kullanıcıları bulundukları yeri, binanın zemin katındaki ticari işleve ve binaların cephe özelliklerine göre tanımlamıştır. Son dönemde Çiftlik Caddesi yayalaştırılmış ve caddenin her iki ara yüzünde bulunan binaların cepheleri yenilenmiştir. Bu değişimin caddenin kentsel kimliği üzerinde güçlü bir etkisi olduğu söylenebilir (Tablo 5).

Anket sonuçlarına göre, cadde kullanıcılarının genel olarak caddedeki değişimi gerekli bulduğu, caddenin yayalaştırılmasından memnun olduğu belirlenmiştir. Buna karşın, lisans eğitimini tamamlamış katılımcılar arasın- 
da eşit dağılım söz konusudur. Bütün katılımcılar diğer sorularda genelde olumsuz görüş bildirmiştir. Katılımcıların çoğunluğu, yenilenen bina cephelerinden memnun değildir. Cepheler estetik ve yangın güvenliği açısından uygun bulunmamıştır. Aynı zamanda, bina cephelerinin birbirine benzemesi de olumsuz karşılanmıştır. Bu sonuçlar, anket gruplarına göre de değişmemektedir. Ancak caddede çalışanların ve 18-29 yaş grubunda olanların memnuniyet düzeyi diğerlerine göre yüksektir. İlköğretim/Ortaokul ve Ön Lisans mezunlarının da değişimden daha fazla memnun olduğu söylenebilir. Katılımclardan erkek, 50 ve üstü yaş grubu, lise mezunu ve caddede yaşayanların birbiriyle uyumlu ve tutarlı yanıtlar verdikleri görülmektedir.

Tablo 5. Çiftlik Caddesi'nin değişim süreci ve oluşan etkiler

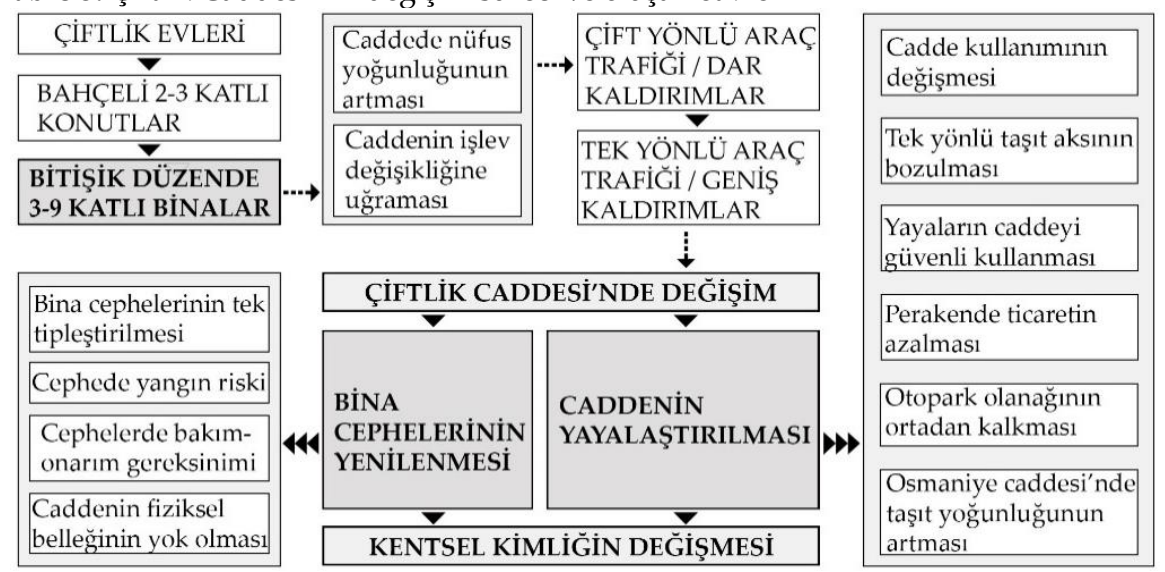

Çalışmadan elde edilen bulgular sonucu, Çiftlik Caddesi'nde değişimden kaynaklanan birçok mekânsal etki belirlenmiştir. Bu etkiler aşağıda yayalaştırma ve cephe yenileme olmak üzere iki başlık altında ayrı ayrı tartışılmakta ve öneriler geliştirilmektedir.

\section{Caddenin Yayalaştırılmasıyla Oluşan Mekânsal Etkiler}

İyi bir caddenin amacı, kent halkının gereksinimlerine kolayca ulaşmalarını sağlamak ve bir yerden bir yere hareketlerini kolaylaştırmaktır. Kentlerdeki yayalaştırma uygulamaları, kent merkezlerini motorlu taşıt trafiğinden arındırarak, yeniden insan ölçeğinde tasarlanmış mekânlara dönüştürmeyi amaçlamaktadır (Tarakçı Eren, Düzenli ve Akyol, 2018, s.490). Taşıt trafiğine açık olan bir yolda insanlar taşıtlarını kullandıkları için, çevreleriyle fazla iletişim kuramaz. Yayalaştırılmış bir alanda ise, bireylerin çevre 
algisı artmaktadır. Kentsel alanlarda yayalaştırmanın kente çevresel, ekonomik ve daha birçok katkısı olduğu bilinmektedir. Çiftlik Caddesi, alışveriş olanağının yanı sıra, sosyal gereksinimlere de yanıt verebilen bir merkez ve rekreasyon mekânıdır. Yaya yoğunluğunun ve hareketinin fazla olduğu bu tür caddelerin taşıt trafiğinden arındırılması, yayaların güvenliği ve hareket konforu yanı sıra, kentsel alandaki hava ve gürültü kirliliğinin azaltılması için de önemlidir.

Caddelerin yayalaştırmasında sürdürülebilirliğin sağlanması, kullanıcıların sahiplenme düzeyiyle ilişkilidir. Çiftlik Caddesi kullanıcıları yayalaştırılmış alanlarda hem gezme, dinlenme, eğlenme hem de rahat bir alışveriş yapma olanağı bulabilmektedir. Caddenin konforlu ve güvenli bir biçimde yürünebilir bir aks haline getirilmesini ve yayalaştırmayla yürüyenlere geniş alanlar ayrılmasını, katılımcıların çoğunlukla $(\% 68,3)$ olumlu karşıladığı belirlenmiştir. Ancak caddedeki iş yeri sahipleri, Çiftlik Caddesi'nin taşıt trafiğine kapatılmasından memnun olmadıklarını sözlü olarak iletmişlerdir. $\mathrm{Bu}$ işletmeciler, caddenin tek yönlü taşıt trafiğine açılmasından ve cadde üzerinde otopark ceplerinin düzenlenmesinden sonra, taşıtlı cadde kullanıcllarının perakende ticareti hareketlendirdiğini bildirmekte ve caddenin taşıt trafiğine kapatılmasıyla birlikte alışveriş hareketliliğinin azaldığını düşünmektedir. BSBEEP kapsamında geliştirilen Çiftlik Caddesi AVM projesiyle güçlü bir alışveriş aksı olması beklenen Çiftlik Caddesi'nin, iş yeri sahiplerinin talebiyle Samsun Büyükşehir Belediyesi tarafından tekrar taşıt trafiğine açılması gündeme gelmiştir. Ancak caddedeki alışveriş hareketliliğinin azalması, yalnızca caddenin yayalaştırılmasıyla açıklanamaz. Samsun kentinde, son yıllarda çok sayıda alışveriş merkezi açılmıştır. 2004 yılında açlan Yeşilyurt, kentte açılan ilk alışveriş merkezidir. Özellikle 2012 yılında açılan Bulvar ve Lovelet'in açık hava alışveriş merkezi olması, Çiftlik Caddesi'ne alternatif mekânlar oluşturmuştur. Daha sonra, 2013 yılında Karadeniz bölgesinin en büyük alışveriş merkezi olan Piazza açılmıştır (Şekil 12). Kent merkezindeki birçok büyük mağazanın bu merkezlere taşınmasının ve kent halkının alışveriş ve yeme içme için bu merkezleri tercih etmesinin Çiftlik Caddesi'ne talebi azalttı̆ğ düşünülmektedir. Dolayısıyla caddedeki alışveriş hareketliliğindeki azalmanın esas nedeni olarak caddenin yayalaştırılması gösterilmemelidir. Aslında güçlü ve etkili bir kentsel hareket olan yayalaştırma, özellikle kentsel alanlarda ticaretin canlandırılması ve yeni yatırımcıların teşvik edilmesi için kullanılan önemli bir araç olarak görülmektedir. Özellikle kent merkezlerindeki uygulamalarda, perakende ticare- 
tin yer aldığı ana caddeler yayalaştırılmaktadır. Çiftlik Caddesi AVM projesi de, caddede azalan alışveriş hareketliğine karşı geliştirilmiş bir projedir.

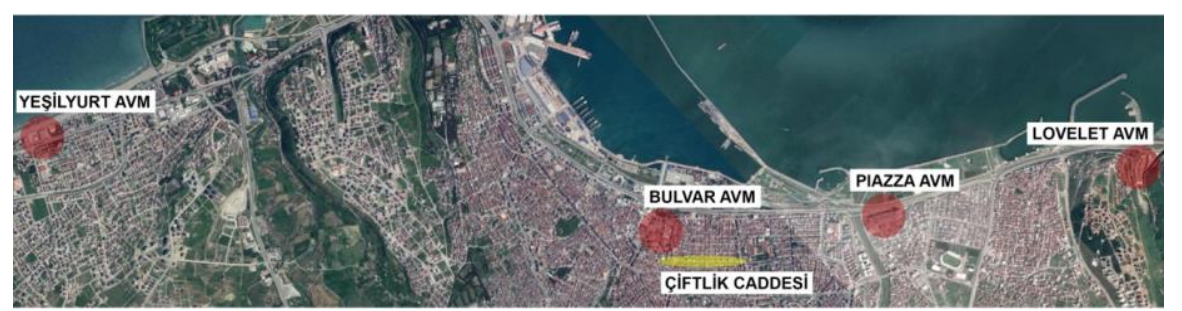

Şekil 12. Samsun'daki alışveriş merkezlerinin konumu

(Uydu görüntüsünden yararlanılarak hazırlanmıştır.)

Caddenin taşıt trafiğine kapatılmasıyla ortaya çıkan birçok mekânsal etki vardır. Bu etkiler; 19 Mayıs Bulvarı'ndan gelen taşıtların Gazi Caddesi ve 56 'lar semtine ulaşımının engellenmesi, bu yönden gelen taşıtların Osmaniye Caddesi'ne zorunlu olarak yönlendirilmesi ve Osmaniye Caddesi'nin taşıt yoğunluğunun artması şeklinde sıralanabilir. Ayrıca bu bölgede cadde kullanıcılarının araçlarını park etme olanakları da sınırlanmıştır. Çiftlik Caddesi'nin tamamının tekrar taşıt trafiğine açılması, hem yayaların konforu ve güvenliği hem de yatırım giderleri açısından olumlu karşılanmamaktadır. Caddenin taşıt trafiğine tekrar açılabilmesi için, cadde boyunca araç ve yaya yollarının yeniden düzenlenmesi, yol tesisatının ve yüzey kaplamalarının değiştirilmesi gereklidir. Bu yeni düzenleme ve değişiklik ekonomik olmayacaktır. Bunun yerine, caddenin Osmaniye Caddesi ile Ağabali Caddesi arasında kalan $~ 120 \mathrm{~m}$ uzunluğundaki bölümünün taşıt trafiğine açılması daha uygun olabilir (Şekil 13). 


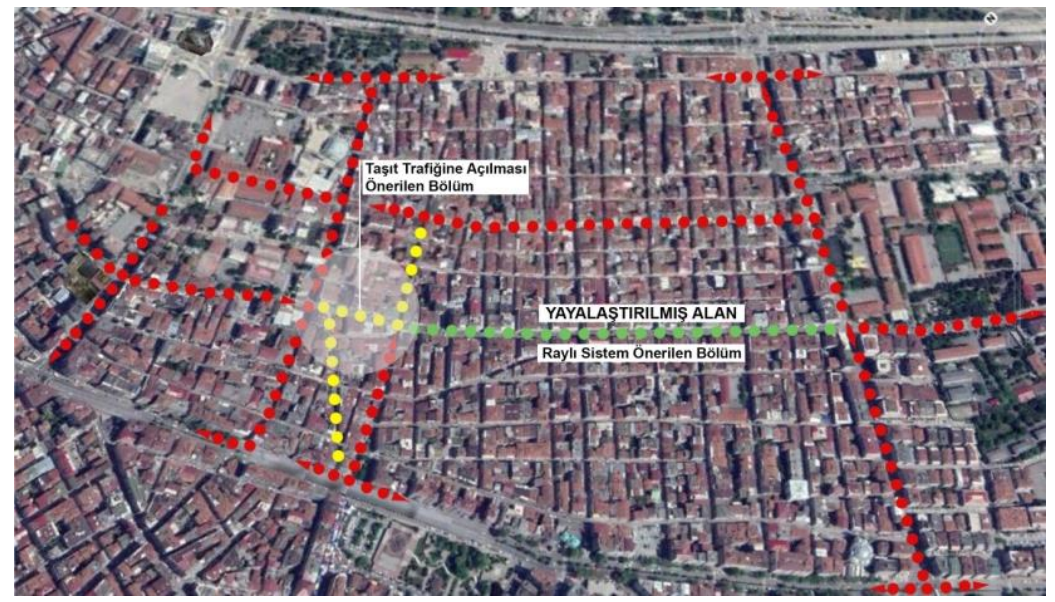

Şekil 13. Çiftlik Caddesi'nde öneri düzenleme

(Uydu görüntüsünden yararlanılarak hazırlanmıştır.)

Caddenin tekrar taşıt trafiğine açılması önerilen bu bölümünde, restoran olarak kullanılan Elmas Hanım Konağ ile birlikte 2 pasaj girişi, 4 bina girişi, 26 iş yeri bulunmaktadır. Böylece yayalaştırılmış alan uzunluğu azalan Çiftlik Caddesi'nden hem Alp Gündem Sokak kullanılarak, yeni bir düzenlemeyle 100. Yıl Bulvarı'nın Modern Pazar Kavşağına ulaşılabilir, hem de Ağabali Caddesi üzerinden Gazi Caddesi'ne doğru taşıt trafiği düzenlenebilir. Alp Gündem Sokağın taşıt trafiğine açılmasıyla Osmaniye Caddesi'ndeki taşıt yoğunluğunun azalacağı öngörülmektedir. Caddenin bu bölümünde park etme ve işyerlerine doğrudan servis verme olanağı da sağlanabilir. Çiftlik Caddesi'ne yakın bölgelerde, caddeyi kullananların taşıtlarını park edebilecekleri alternatif alanlar yaratılmalıdır. Ayrıca caddenin yayalaştırılan bölümünde raylı sistem düzenlenebilir. Bu sistem yayaların cadde boyunca ulaşımını kolaylaştıracağı gibi, aynı zamanda caddenin alışveriş hareketliliğini de arttrabilir (Şekil 14). 


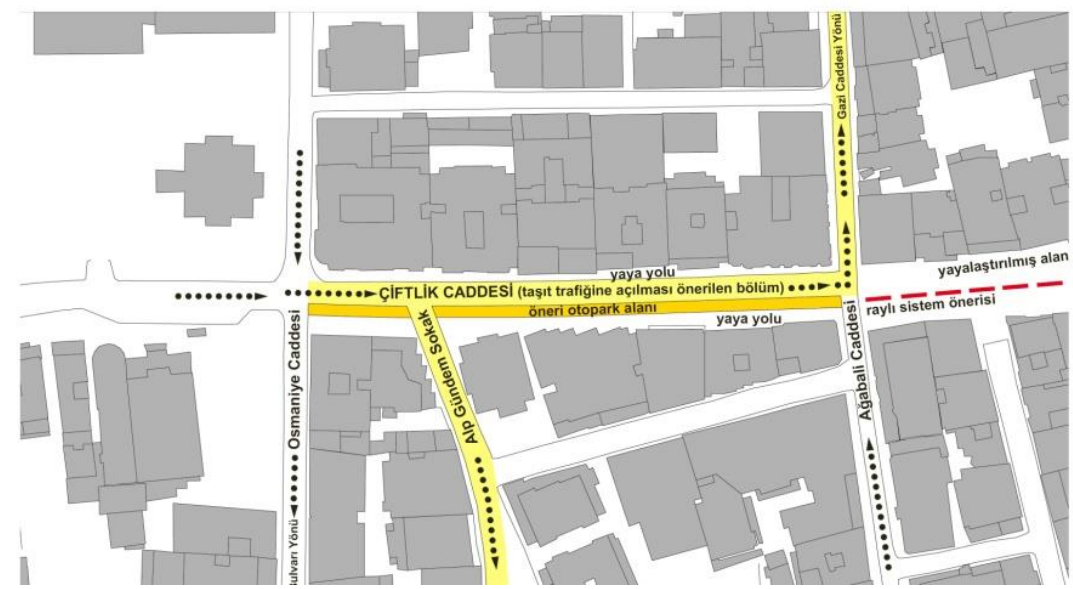

Şekil 14. Çiftlik Caddesi'nde taşıt trafiğine açılması önerilen bölüm

\section{Bina Cephelerinin Yenilenmesiyle Oluşan Mekânsal Etkiler}

Çiftlik Caddesi'nde bina cephelerinin yenilenmesinden kaynaklanan üç temel mekânsal etki vardır. Bina cephelerindeki birinci etki, yangın tehlikesidir. Caddede bulunan binaların cephelerinde kullanılan genleştirilmiş polistren yangına maruz kaldığında tutuşma görülmekte ve isı yayınımı gerçekleşmektedir. Bu ürünler doğru uygulandığında aşırı yangın tehlikesi oluşturmaz. Bunun için, EPS ürünler koruyucu bir yüzey malzemesiyle tam olarak kaplanmalıdır (Uygunoğlu, Güneş, Çalış ve Özgüven, 2015, s.22).

Çiftlik Caddesi'ndeki binaların dış cephelerinde uygulanan EPS blokların ön yüzeyleri önceden kaplanmıştır. Ancak blokların arka ve yan yüzeylerinin dış etkenlere açık olması ve cephe yüzeyinin kesintisiz koruyucu kaplamayla sarılmaması nedeniyle yangın riski bulunmaktadır. Ayrıca EPS blokların yüzeylerindeki katmanın zaman içinde dökülmesi, blokların birbirinden ayrılması ve bloklarda kopmalar olması sonucu yangın riski artacaktir.

Bina cephelerindeki ikinci etki, yenilenen cephelerde kısa sürede bakıma ve onarıma gereksinim duyulmasıdır. Çiftlik Caddesi'ndeki bina cephelerinin bir bölümünde EPS blok ürünler kullanılmıştır. Bazı cephe bölümlerinde de bloklar üst üste uygulanmıştır. Bu tür ürünlerin cepheye montajı zordur ve zaman içinde, uygulama zorluğu ve montaj hataları nedeniyle EPS bloklar cepheden ayrılabilir ve düşebilir. Caddedeki bazı binaların cephelerinde yapılan onarım çalışmaları bu görüşü desteklemektedir (Şekil 15). Bu nedenle binalarda yangın riskinin yanı sıra, ileriye yönelik kaplama ve yalıtım sorunlarının ortaya çıkması kaçınılmazdır. Binanın kullanım aşamasın- 
da, cephedeki geniş çıkıntıların kısa sürede kirlilik oluşturması, EPS blokların kopması veya düşmesi nedeniyle değiştirme, temizlik ve boya yapma gibi gereksinimler ortaya çıktığında, cephelerin bakım-onarım maliyeti artacaktır.

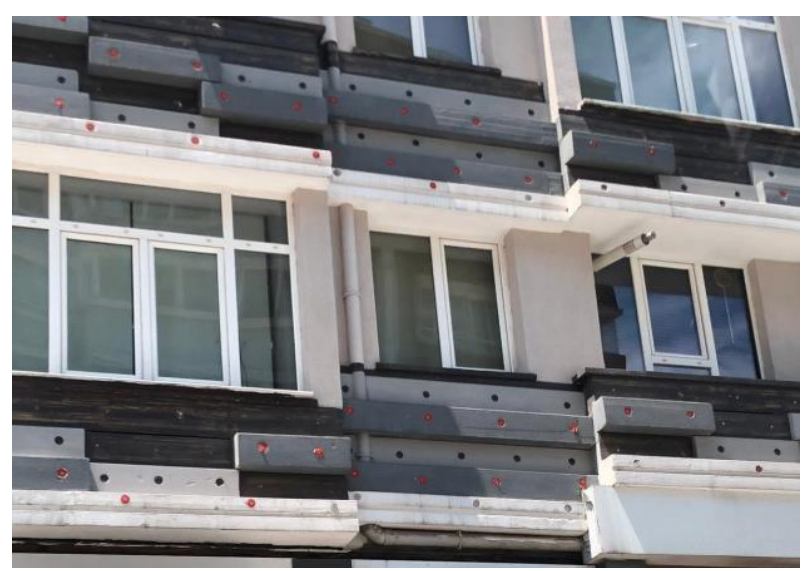

Şekil 15. Yenilenen bina cephelerinde onarım yapılması

Binaların cephelerindeki üçüncü etki, bina cephelerinin tek tipleştirilmesidir. Caddenin her iki yönünde konumlanan bina cephelerinin ayn malzemeyle benzer biçimde yenilenmesi, cadde boyunca tekrar eden cephe silüetleri ortaya çıkartmıştır (Şekil 16a, b). Oysa caddeyi tanımlayan bina cephelerinin biçimsel özellikleri, kent kimliği üzerinde etkili olmakta ve kamusal alanlarda, kentsel kimlikle birlikte kullanıc belleğinin oluşmasını sağlamaktadır. Çevreden elde edilen her türlü uyarı, bireyde belleğe kodlanan bir iz bırakmaktadır. Mekânı deneyimleyen bireyin mekânın kimliğiyle karşılıklı etkileşimi söz konusu olduğundan, birey ayrıntıları fark etmekte ve fark ettiği ayrıntıları herhangi bir çağrışımla geri getirmek üzere belleğine kaydederek mekânı kodlamakta ve kendisi için özelleştirmektedir (Sayar Avcıoğlu ve Akın, 2017, s.431). Bu bağlamda caddenin görsel özellikleri mekâna bir karakter kazandırmakta ve caddenin kimliğinin oluşmasına doğrudan etki eden binalar ve diğer fiziksel bileşenler kentsel bellek oluşturmaktadır. Çiftlik Caddesi'nin fiziksel çevresinde yaşanan değişimler ise, bir yandan eski mekân belleğinin yok olmasına neden olurken, diğer yandan da yeni bir bellek oluşmasını engellemektedir. Caddede ayn kentsel donatı elemanlarına yer verilmesi de, birbirine benzeyen cephelerin olumsuz etkisini güçlendirmekte ve cadde kullanıcılarının çevre algısını azaltmaktadır. Bu nedenle Çiftlik Caddesi'nde oluşan yeni silüetler yalnızca 
estetik açıdan değerlendirilmemelidir. Yön bulma, mesafeyi algılama, binaları tanıma, bulunduğu yeri anlama gibi etkenler açısından da ele alınmalıdir.

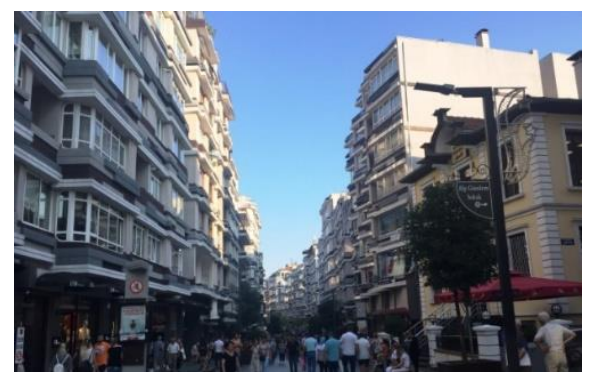

a. Osmaniye Caddesi girişi

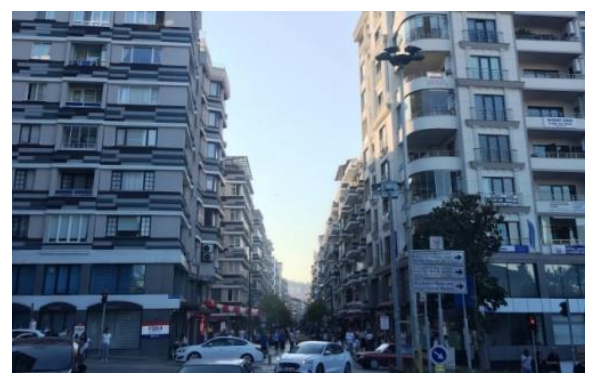

b. Lise Caddesi girişi

Şekil 16. Çiftlik Caddesi'nin yeni dokusu

Genel olarak caddede en çok vakit geçirenlerin caddede yaşayanlar olduğu ve bu kullanıcıların bina cephelerini Çiftlik Caddesi'ne uygun bulmadıkları görülmektedir. Mekânların işlevsel gereksinmeleri karşılaması dışında, kullanıcıların psikolojik olarak hoşnut olmalarını sağlayacak oran, renk, doku gibi görsel etkiye dayalı birçok estetik değer de bulunmaktadır (Korur, Sayın, Oğuzalp ve Korkmaz, 2006, s.179). Kullanıcılar, içinde bulundukları mekânı değerlendirirken, çoğu kez işlevsel gereksinimlerle estetik değerleri birbirinden ayırmaktadır. Örneğin; caddede yaşayanların \%64'ü Çiftlik Caddesi'ndeki değişim projesini gerekli bulup desteklemekte, \%68'i caddenin yayalaştırılmasından dolayı memnuniyet duymaktadır. Buna karşın, aynı katılımcıların \%72'si bina cephelerinin birbirine benzemesini olumsuz karşılamakta, \%51,7'si ise yenilenen bina cephelerini estetik bulmamaktadır. Katılımcıların çoğunluğunun caddeyi bu şekilde değerlendirmesinin, caddede kullanılan renklerden ve cephelerin tek tipleştirilmesinden kaynaklandığı düşünülmektedir. Bu nedenle caddelerde değişim yapılırken, kent halkının beklentilerinin ayrıntılı bir biçimde belirlenmesi doğru bir yaklaşım olacaktır.

Kentte estetiğin sağlanması ve kent halkının gereksinimlerinin karşılanması için, eskiyen bina cephelerinin ve caddelerin yenilenmesi, bazı caddelerin yayalaştırılması doğru bir yaklaşımdır. Ancak kent halkının birçok işlevi bir arada bulabileceği estetik ve konforlu alanların özenle ve gereksinimler önemsenerek tasarlanması önemlidir. Katılımcların çoğunluğu caddeyi estetik bulmazken, cinsiyete ve caddede bulunma durumuna göre estetik algının oranları değişmektedir. Caddeyi kullananlar, yüksek bir 
oranda caddenin estetik olmadığını düşünmektedir. 18-29 yaş arası katılımcıların diğer yaş gruplarına göre farklı yanıtlar vermelerinin, caddenin eski durumunu bilmemelerinden kaynaklandığı söylenebilir. Bu nedenle cephe yenileme çalışmalarında ve cephelerde ürün seçiminde her bina kendi özelinde değerlendirilmelidir. Cepheleri tek tipleștirmek yerine, cadde ve bina kimliğini yansıtan farklı bina cepheleriyle cadde silüeti oluşturulabilir. Bunun için, caddedeki bina cephelerinde, caddenin kimliğini koruyacak yeni bir uygulama yapılması uygun olabilir. Bu uygulama, ekonomik olmamasına karşın, caddedeki yangın riskini ortadan kaldırabilir, bina cephelerinin bakım-onarım giderlerini azaltabilir, bina cephelerinde tek tipleştirilen etkiyi değiştirebilir ve caddeye farklı bir kentsel kimlik kazandırabilir.

\section{Sonuç}

Samsun, birbirinden farklı özellikte bölgelere sahip olan, birçok kültürü barındıran, yaşayan dinamik kimliği ve lineer gelişen boyutuyla her geçen gün nüfusu artan, kentsel alanları yoğunlaşan ve bununla birlikte çözülmesi gereken birçok sorunu barındıran bir kenttir. Bu nedenle kent sınırları içinde, kentsel tasarım ve uygulamaları yönlendirebilecek ve çağdaş anlamda çözümler üretebilecek, bazen estetik ve kalite gözeterek esnek, bazen de kent dokusunu korumak ve ortak bir dil oluşturmak için kararlı ve taviz vermeyen, yalın, anlaşılabilir ve yol gösterici çözümler üretilebilir. Samsun kentinin en önemli caddelerinden biri olan Çiftlik Caddesi, kentin bütünüyle olan ilişkisinden ve tarihi sürecinden dolayı sosyalleşme mekânı özelliği kazanmıştır. Tarihsel süreç içinde her zaman şehrin en önemli mekânlarından biri olan bu cadde ve çevresindeki yaşam, bugün de bu özelliğini korumaktadır. Çalışma kapsamında yapılan anketin sonuçlarına bakıldığında, kent halkı caddenin güvenli ve konforlu, yürünebilir bir mekâna dönüşmesinden ve yayalaştırmayla yürüyenlere geniş alanlar ayrılmasından memnuniyet duymaktadır. Dolayısıyla Çiftlik Caddesi'nin taşıt trafiğine kapatılması, kent halkının çoğunluğu tarafından olumlu karşılanmaktadır. Ancak iş yeri sahipleri ayn fikirde değildir. Bu nedenle caddenin yeniden taşıt trafiğine açılması gündeme gelmiştir. Bu yaklaşım gözden geçirilmeli ve caddenin alışveriş potansiyelindeki azalmanın nedenleri doğru belirlenmelidir.

Kent estetiğinin sağlanması, binalardaki sorunların önlenmesi ve kent halkının gereksinimlerinin karşılanması için, eskiyen bina cephelerinin yenilenmesi önemlidir. Genelde kullanıcıların Çiftlik Caddesindeki cephe yeni- 
leme çalışmalarını destekledikleri belirlenmiştir. Ancak yenileme çalışmaları sonucunda, cephelerin tekrar eden bir etki yaratmasindan dolayı, katılımc1ların çoğunluğunun memnun olmadıkları anlaşılmaktadır. Bu nedenle cephelerde caddeye boyut kazandıran tasarımlar yapılması ve bina tasarımıla uyumlu ürünler kullanılması, kullanıcıların belleklerindeki beklentilerle uyumlu olacaktır.

Her binanın farklı bir kimliği olmasına karşın, Çiftlik Caddesi'nde birbirine benzeyen ve tekrar eden uygulamalar, ayırt edilemeyen ve tanımlanamayan bina cepheleri oluşturmuştur. Bu uygulamanın tek tipleşen cephelerin ortaya çıkmasına, caddenin ve binaların kimliğinin yok olmasına ve caddeyi kullananlarda fiziksel izlerin kaybolmasına neden olduğu söylenebilir. Dolayısıyla Çiftlik Caddesi'nde bulunan binaların cephelerinde monotonluğa doğru bir yönelim olmuş ve tekrar eden cepheler ön plana çıkmıştır. Bu durum caddeyi kullananların çevresine ilgisini azaltmaktadır. Oysa binaların yüzü olan cepheler, taşıdığı işaretler yoluyla çevreyle iletişim kurmaktadır. Cephe, biçimsel bir kurgudan daha çok, yüklendiği anlamla kentin dilini oluşturur. Bu nedenle cephe tasarımlarında, monoton, sıradan ve birbirine benzeyen cepheler yerine; boyut, biçim ve renk olarak belirgin, çevresiyle ortak bir dil oluşturabilen özgün cepheler tercih edilmelidir.

Binalarda meydana gelen dış cephe yangınları son yıllarda artış göstermiştir. Bunun nedeni, cephelerde kullanılan kaplama ürünlerinin yanıcılık sınıflarının düşük olmasıdır. EPS gibi ürünler yüksek yangın riski oluşturmakta, yangının cepheye, binaya ve çevreye yayılmasına neden olabilmektedir. Cephelerdeki mimari detaylar da, yangının etkisini artırmaktadır. Çiftlik Caddesi'ndeki bina cephelerinde EPS ürünler kullanılması ve yangına yönelik önlemler alınmaması nedeniyle binalarda yangın riski bulunmaktadır. Katılımcıların bir bölümü, bina cephelerinde EPS ürünler kullanıldığının farkındadır. Buna bağlı olarak ankette yangın güvenliği sorgulandığında, caddeyi kullananların çoğunlukla bina cephelerini yangın güvenliği açısından uygun bulmadığı belirlenmiştir.

Sonuç olarak caddelerin yayalaştırılmasında ve bina cephelerinin yenilenmesinde caddelerin mevcut kentsel kimliği göz ardı edilmemeli, kullanıcı memnuniyeti önemsenmeli, kullanıcı gereksinimleri ve bildirimleri değerlendirilmelidir. Mevcut kentsel alanlar ve yapı stoku yenilenerek kullanıma kazandırılırken, insana ve çevreye zararlı olmayan, kullanıc güvenliğini göz ardı etmeyen, estetik ve sürdürülebilir ürün seçimine önem verilmelidir. Kent caddelerinin tasarımı, bütün kent paydaşlarıyla birlikte gerçekleştirilmelidir. 


\title{
Extended Abstract
}

\section{A Research on the Spatial Effects of Changes in Streets: Samsun Çiftlik Street}

\author{
Erkan Avlar6 \\ ORCID: 0000-0003-0492-8095
}

\author{
Burcu Yazic1 ${ }^{7}$ \\ ORCID: 0000-0002-9932-2979
}

Streets are cities' most dynamic spaces, and they are constantly changing. Changes in streets - which are public spaces-include many different applications ranging from the pedestrianization of streets to the renewal of buildings that front streets. Pedestrianization is carried out in order to designate city roads as strictly walkable areas and to allocate wider areas to pedestrians. Building façades are renovated when, over time, they cease to respond to user requirements and demands due to various factors. While changes in streets offer different opportunities to urban life and streets, sometimes they may also cause problems.

In recent years, there have been changes in streets in many cities, and local administrations are prioritizing change projects. Samsun Çiftlik Street is an example of an urban space that has been pedestrianized and whose building façades have been renovated. The changes on Çiftlik Street were made as part of the Black Sea Buildings Energy Efficiency Plan (BSBEEP) as per the Samsun Urban Aesthetics Committee decision. This urban project was prepared with the goal of giving both the street and the buildings that front on the street new identities, as well as transforming Çiftlik Street into a strong shopping axis by prohibiting vehicle traffic and renewing the infrastructure and the building façades.

This change project referred to as the Çiftlik Street Shopping Mall was financially supported $75 \%$ by building owners and $25 \%$ by the Samsun Metropolitan Municipality. However, business owners have recently requested

\footnotetext{
${ }^{6}$ Assoc. Prof. Dr., Yıldız Technical University, E-mail: eavlar@yildiz.edu.tr

${ }^{7}$ Ylldız Technical University, E-mail: burcuyazici90@gmail.com

idealkent @ Kent Araştırmaları Dergisi (Journal of Urban Studies) 
reopening the street to vehicle traffic, as they think that shopping activity has decreased since the changes were made. In addition, experiencing so many problems related to façade renovation in such a short time affected user satisfaction negatively. Therefore, this study is important for increasing the shopping potential of Çiftlik Street, and for ensuring that users wander the street more comfortably, as well as for discussing and developing suggestions regarding the value of change projects carried out to increase the attraction of streets, and their effects on the users of the street.

The purpose of this study is to investigate the level of value added to the city in aesthetic, social and economic terms, the consequences of pedestrianizing the street and renovating the building façades, the level of user satisfaction regarding the changes to the street, and whether these changes lead to problems. For this purpose, the physical condition of Samsun Çiftlik Street was examined, its spatial properties were determined, and users' satisfaction levels of the changes to the street were measured. Focusing especially on the example of this street, the study consists of two stages: due diligence and survey.

According to survey results, street users generally find the changes to the street to be necessary and are satisfied with the pedestrianization of the street. Interestingly, there is an equal distribution among participants with undergraduate degrees. All participants generally expressed negative opinions regarding other questions. A majority of participants are not satisfied with the renovated building façades, finding them unsuitable both aesthetically and for reasons of fire safety. At the same time, the buildings' resemblance to each other is viewed negatively. These results also apply to survey groups. On the other hand, satisfaction levels of those who work on the street and those aged 18-29 is higher than others. It can be said that Primary/Secondary School graduates and associate degree holders are more satisfied with the changes. It is observed that those aged 50 and higher, high school graduates, street residents, and men all provided comparable and consistent responses.

Closing the street to vehicle traffic caused many spatial effects: the blocking of vehicles from 19 Mayıs Boulevard to Gazi Street and 56's district, the mandatory routing of vehicles from this direction to Osmaniye Street, and this street's subsequently increased vehicle density. In addition, parking spaces are also limited in this area. Re-opening the entire length of Çiftlik Street to vehicle traffic is not viewed positively in terms of both the comfort and safety of pedestrians and the investment costs, as it would require rearranging the street's vehicle lanes and pedestrian walkways, and renewing road installations and surface treatments. This new rearrangement and change would not 
be economical. Instead, it may be more viable to allow vehicle traffic on the $\sim 120 \mathrm{~m}$ long section of the street between Osmaniye and Ağabali Streets.

Spatial effects have also arisen as a result of the renovation of the building façades on Çiftlik Street, the first of which is the fire hazard. Building façade fires have increased in recent years. One reason for this is the low flammability class of the coating products used on the façades. Products such as EPS carry a high fire risk and can cause fires to spread to façades, buildings, and the surroundings. Also, architectural details on the façades can increase the effects of fires. There is a risk of fire in buildings due to the use of EPS products on the building façades on Çiftlik Street and the lack of fire measures. Some of the survey participants were aware that EPS products were used on the building façades. Accordingly, when questioned regarding fire safety, a majority of street users consider building façades unsuitable.

The second effect of renovating the building façades is the need for maintenance and repair work in a short period of time. EPS block products were used on parts of the building façades on Çiftlik Street, in some cases placing blocks one on the top of the other. Mounting such products to façades is difficult, and over time, EPS blocks may separate and fall due both to this difficulty and to mounting errors. Repair work on the façades of some buildings on the street supports this view. Therefore, in addition to the risk of fire, coating and insulation problems are inevitable in the future. Over the life of the building, maintenance and repair costs of the façades will increase as the large protrusions of EPS blocks fall or break off, creating pollution and requiring replacement, cleaning, and painting.

The final effect is the homogenization of the building façades. Although each building has a different identity, similar and repetitive practices along Çiftlik Street have created indistinguishable and unidentifiable building façades. It can be said that this application has caused uniform façades to emerge, the individual identities of the street and buildings to disappear, and the street to lose its physical impressions on users, reducing their interest in their surroundings. Thus, there has been a tendency towards monotony on the façades of the buildings on Çiftlik Street and the repetitive façades have come to the fore. However, façades are the faces of buildings, and they communicate through the signs they carry. The façade is more than a formal design; rather, it creates the language of the city through the meaning it conveys. Therefore, façades should be designed that are distinctive in size, form, and color, and should form a common language with their surroundings rather than be monotonous, ordinary, and identical. 
In conclusion, the existing urban identity of streets should not be ignored when pedestrianizing and refurbishing building façades. User satisfaction should be taken into consideration and user requirements and opinions should be evaluated. When existing urban areas and building stocks are renewed and made better use of, it's important to select aesthetic and sustainable products that are not harmful to people and the environment, and do not ignore user safety. In this sense, city streets should be designed together with all city stakeholders.

\section{Kaynakça/References}

Altunbaş, U. (2006). Kent merkezlerinde yayalaştırmanın işlevsel değişim üzerine etkileri: istiklal caddesi örneği. Yayınlanmamış yüksek lisans tezi. İstanbul Teknik Üniversitesi Fen Bilimleri Enstitüsü, İstanbul.

Başarır, B. ve Şahin Diri, B. (2014). Bina cephelerinin yenilenmesinde kullanılan stratejiler. 7. Ulusal Çatı \& Cephe Sempozyumu (3-4 Nisan 2014), Yıldız Teknik Üniversitesi, İstanbul, 109-119.

Brambilla, R. and Longo, G. (1977). For pedestrians only, planning, design and management of traffic-free zones. Whitney Library of Design, New York.

Samsun Büyükşehir Belediyesi (2019). Foto galeri. 05.09.2019 tarihinde http://en.samsun.com.tr/images/galeri/800x600/8ef7640e-40f0-4ae0-b9f448f7977d9ed1.jpg adresinden erişilmiştir.

Erturan, B. ve Eren, Ö. (2018). Bina cephelerinin yenilemesine karar vermek için kullanulabilecek bir değerlendirme modeli. MEGARON YTÜ Mimarlık Fakültesi EDergisi, 13(1), 24-38.

İpek, N., Yılmaz, C. ve Seylan, A. (2016). Fotoğraflarla Samsun. Samsun Büyükşehir Belediyesi Kültür Yayınları, Samsun.

Jacob, M. (2007). The drivers of and barriers to energy efficiency in renovation decisions of single-family home-owners. CEPE Working paper no: 56, Centre for Energy Policy and Economics Swiss Federal Institutes of Technology, Zurich.

Jacobs, A.B. (1993). Great streets. The MIT Press, London.

Karadeniz Rumeli Dernekleri Federasyonu (2019). 21.07.2019 tarihinde https://i.pinimg.com/originals/71/0f/09/710f097e6c914b894124e9480e19c9c7.jpg adresinden erişilmiştir.

Karamanlıŏlu, Ş. (2011). Enerji etkin bina cephe sistemlerine yönelik yaklaşımlarm irdelenmesi. Yayınlanmamış yüksek lisans tezi. Dokuz Eylül Üniversitesi Fen Bilimleri Enstitüsü, İzmir.

Kayıkçı A, (2000). Mahalleden bölgeye Samsun. Aksiseda Matbaası, Samsun.

Keleş, R. (1980). Kentbilim terimleri sözlü̆̆ü. Türk Dil Kurumu Yayınlanı, Ankara. 
Korur, S., Sayın, S., Oğuzalp, E.H. ve Korkmaz, S.Z. (2006). Konutlarda kullanıcı gereksinmelerine bağlı olarak yapılan cephe müdahalelerinin fiziksel çevre kalitesine etkisi. Selçuk Üniversitesi Mühendislik Mimarlık Fakültesi Dergisi, 21(3-4), 177-189.

Marshall, S. (2005). Streets \& Patterns. Spon Press, Taylor \& Francis Group, London and New York.

Pekşen, C. (2015). Kamusal bir alan olarak cadde: Bă̆dat Caddesi örneği. Yayınlanmamış yüksek lisans tezi. Yıldız Teknik Üniversitesi Fen Bilimleri Enstitüsü, İstanbul.

Samsun Web Rehberi (2014). 21.07.2019 tarihinde https://i.pinimg.com/originals/8a/3d/82/8a3d82d2ad2b0dc9ded306d11d81df11.jpg adresinden erişilmiştir.

Samsun Büyükşehir Belediyesi (2014). 2015-2019 Stratejik Planı, Samsun.

Sayar Avcıoğlu, S. ve Akın, O. (2017). Kolektif bellek ve kentsel mekân algısı bağlaminda İstanbul Tuzla Köyiçi Koruma Bölgesi'nin mekânsal değişiminin irdelenmesi, İdealkent Kent Araştırmaları Dergisi, 22(8), 423-450.

Sezgin, H. (2015). Black Sea buildings energy efficiency plan. $4^{\text {th }}$ Steering Committee Meeting (30-31 July 2015), Kavala.

Tarakçı Eren, E., Düzenli, T. ve Akyol, D. (2018). Kent merkezinde caddelerin yayalaştırılması: Trabzon Kahramanmaraş Caddesi örneği. MEGARON YTÜ Mimarlık Fakültesi E-Dergisi, 13(3), 480-491.

Uygunoğlu, T., Güneş, İ., Çalış, M. ve Özgüven, S. (2015). EPS ve XPS malzemeleriyle yapılan mantolamaların yangın sırasındaki davranışlarının araştırılması. Politeknik Dergisi, 1(18), 21-28. 